\title{
Toward a systematic framework for research on dominant designs, technological innovations, and industrial change
}

\author{
Johann Peter Murmann ${ }^{a, *}$, Koen Frenken ${ }^{b, 1}$ \\ a Australian Graduate School of Management, Sydney, NSW 2052, Australia \\ ${ }^{\mathrm{b}}$ Urban and Regional Research Center Utrecht (URU), Section of Economic Geography, Faculty of Geosciences, \\ Utrecht University, P.O. Box 80115, NL-3508TC Utrecht, The Netherlands
}

Received 5 March 2005; received in revised form 14 February 2006; accepted 15 April 2006

Available online 7 July 2006

\begin{abstract}
The concept of a dominant design has taken on a quasi-paradigmatic status in analyses of the link between technological and industrial dynamics. A review of the empirical literature reveals a variety of interpretations about some aspects of the phenomenon such as its underlying causal mechanisms and its level of analysis. To stimulate further progress in empirical research on dominant designs, we advocate a standardization of terminology by conceptualizing products as complex artifacts that evolve in the form of a nested hierarchy of technology cycles. Such a nested complex system perspective provides both unambiguous definitions of dominant designs (stable core components that can be stable interfaces) and inclusion of multiple levels of analysis (system, subsystems, components). We introduce the concept of an operational principle and offer a systematic definition of core and peripheral subsystems based on the concept of pleiotropy. We also discuss how the proposed terminological standardization can stimulate cumulative research on dominant designs.
\end{abstract}

Crown Copyright (C) 2006 Published by Elsevier B.V. All rights reserved.

Keywords: Dominant designs; Evolution of artifacts; Architecture of complex systems; Product life cycle

\section{Introduction}

The model of a product life cycle and the concept of a dominant design have received considerable scholarly attention in organization theory and in industrial organization (Suarez, 2004). The notion of a dominant design has stimulated a surge in empirical investigation over the past two decades (Table 1 provides an analytic overview of all the empirical studies we have been able to find). For a large scholarly community, the ideas surrounding the

\footnotetext{
* Corresponding author. Tel.: +61 299319258.

E-mail addresses: rp@professor-murmann.net (J.P. Murmann), k.frenken@geo.uu.nl (K. Frenken).

1 Tel.: +31 30253 2466; fax: +31 302532037 .
}

concept of a dominant design have taken on the function reminiscent of Kuhn's notion of conceptual paradigms in the development of science.

One of the central notions in the writings on dominant designs is the idea that the emergence of a dominant design in a product category changes the relative focus of research and development (R\&D) efforts from product innovations to process innovations (Abernathy and Utterback, 1978). In turn, this change in the nature of innovation is seen as having important consequences for market structures. The research program of testing these causal hypotheses, however, has uncovered several conceptual and empirical problems that, in our view, need to be addressed first before further scientific advance is possible that can determine the precise causal role of dominant designs in changing the nature of innovation 
Table 1

Analytical Overview of Empirical Studies on Dominant Designs

\begin{tabular}{|c|c|c|c|c|c|c|c|c|c|}
\hline $\begin{array}{l}\text { Authors, } \\
\text { Publication Date }\end{array}$ & Abernathy and Utterback ( & 1978) & & \begin{tabular}{|l} 
Rosenbloom and \\
Cusumano (1987)
\end{tabular} & $\begin{array}{l}\text { Cusumano, Mylonadis, } \\
\text { and Rosenbloom (1992) }\end{array}$ & $\begin{array}{l}\text { Anderson and Tushman } \\
\text { (1990) }\end{array}$ & & & \\
\hline \multirow[t]{2}{*}{ Topic of Paper } & \multicolumn{3}{|c|}{ Trade-offs between process (productivity) and product innovation } & \multirow[t]{2}{*}{$\begin{array}{l}\text { Technical pioneering and } \\
\text { competitive advantage }\end{array}$} & \multirow[t]{2}{*}{$\begin{array}{l}\text { Strategies for creating } \\
\text { dominant designs }\end{array}$} & \multicolumn{4}{|c|}{ Dominant designs / competence-enhancing and competence-destroying innovations } \\
\hline & & & & & & Technology 1 & Technology 2 & Technology 3 & Technology 4 \\
\hline Level of Analysis & Entire system & Subsystem & Subsystem & $\begin{array}{l}\text { Entire system / } \\
\text { subsystem }\end{array}$ & Entire system/ subsystem & Subsystems & Subsystems & Entire system & Entire system \\
\hline Product Description & Automobile & Automobile engine & $\begin{array}{l}\text { Configuration of parts of } \\
\text { internal combustion } \\
\text { engines }\end{array}$ & $\begin{array}{l}\text { Video cassette recorders, } \\
\text { recording heads }\end{array}$ & Video cassette recorders & $\begin{array}{l}\text { Cement kiln and control } \\
\text { unit of kiln }\end{array}$ & $\begin{array}{l}\text { Central processing unit and } \\
\text { memory }\end{array}$ & $\begin{array}{l}\text { Container glass } \\
\text { machine }\end{array}$ & Flat glass machine \\
\hline $\begin{array}{l}\text { Nature of } \\
\text { Technology }\end{array}$ & Stand-alone product & Component of system & $\begin{array}{l}\text { Collection of } \\
\text { components }\end{array}$ & $\begin{array}{l}\text { Product with network } \\
\text { externalities, component } \\
\text { in system }\end{array}$ & $\begin{array}{l}\text { Product with network } \\
\text { externalities }\end{array}$ & Component of system & Component of system & Stand-alone product & Stand-alone product \\
\hline $\begin{array}{l}\text { Technological } \\
\text { Context }\end{array}$ & \begin{tabular}{|l} 
Transportation \\
infrastructure, gas stations
\end{tabular} & Automobile & $\begin{array}{l}\text { Internal combustion } \\
\text { engine }\end{array}$ & Home electronics & Network of video stores & $\begin{array}{l}\text { Cement production } \\
\text { system }\end{array}$ & Minicomputer systems & $\begin{array}{l}\text { Container glass } \\
\text { production system }\end{array}$ & $\begin{array}{l}\text { Flat glass production } \\
\text { system }\end{array}$ \\
\hline $\begin{array}{l}\text { Technology } \\
\text { Measure }\end{array}$ & & & & & $\begin{array}{l}\text { Compatible/non- } \\
\text { compatible designs }\end{array}$ & Capacity of largest kiln & CPU speed & $\begin{array}{l}\text { Capacity of fastest } \\
\text { machine }\end{array}$ & $\begin{array}{l}\text { Capacity of fastest } \\
\text { machine }\end{array}$ \\
\hline $\begin{array}{l}\text { Market Share } \\
\text { Measure }\end{array}$ & $\begin{array}{l}\text { Percent of Total } \\
\text { Passenger Cars }\end{array}$ & & & $\begin{array}{l}\text { Frequency of one-head } \\
\text { versus two-head designs }\end{array}$ & $\begin{array}{l}\text { Annual production and } \\
\text { cumulative sales by } \\
\text { format }\end{array}$ & New kiln installations & Minicomputer sales by model & $\begin{array}{l}\text { New container glass } \\
\text { machines }\end{array}$ & $\begin{array}{l}\text { New flat glass } \\
\text { machines }\end{array}$ \\
\hline Level of Standard & Entire system & Component & $\begin{array}{l}\text { Configuration of } \\
\text { components }\end{array}$ & $\begin{array}{l}\text { Reading and recording } \\
\text { subsystem }\end{array}$ & Video tape format & Subsystems & $\begin{array}{l}\text { Particular architectural } \\
\text { feature }\end{array}$ & Entire system & Entire systems \\
\hline $\begin{array}{l}\text { Description of } \\
\text { Standard }\end{array}$ & $\begin{array}{l}\text { Ford Model T chassis } \\
\text { (everything except body) }\end{array}$ & $\begin{array}{l}\text { Internal combustion } \\
\text { engine }\end{array}$ & $\mathrm{V}-8$ engine & 2-headed rotating scanner & VHS standard & $\begin{array}{l}\text { Kiln length/architecture } \\
\text { of heating system }\end{array}$ & $\begin{array}{l}\text { 16-bit machine and core } \\
\text { memory, 16-bit moss } \\
\text { memory }\end{array}$ & $\begin{array}{l}\text { Particular machine } \\
\text { name }\end{array}$ & $\begin{array}{l}\text { Particular machine } \\
\text { name }\end{array}$ \\
\hline $\begin{array}{l}\text { DD (Yes, No) } \\
\text { Mechanism Creating } \\
\text { DD }\end{array}$ & $\begin{array}{l}\text { Yes (1908) } \\
\text { Cost reduction }\end{array}$ & Yes (Around1902) & $\begin{array}{l}\text { Yes (1930s) } \\
\text { Invention of automated } \\
\text { production processes }\end{array}$ & Yes & $\begin{array}{l}\text { Yes } \\
\text { Forming alliance with } \\
\text { competing producers }\end{array}$ & 4 out of 5 cases & 2 out of 3 cases & 4 out of 4 cases & 2 out 4 cases \\
\hline $\begin{array}{l}\text { Critical Dimensions } \\
\text { of Success }\end{array}$ & Price, reliability & $\begin{array}{l}\text { Emerging as the better } \\
\text { technology }\end{array}$ & Superior technology & \begin{tabular}{|l} 
Ability to scale down \\
machine and tape, \\
reduction in price to \\
penetrate mass market
\end{tabular} & $\begin{array}{l}\text { Availability of many } \\
\text { prerecorded movies, } \\
\text { manufacturing ability, } \\
\text { network externalities }\end{array}$ & Capacity (energy costs) & Speed & Capacity & Capacity \\
\hline $\begin{array}{l}\text { Difference from } \\
\text { Earlier or Alternative } \\
\text { Designs }\end{array}$ & $\begin{array}{l}\text { Synthesis of } \\
\text { independently introduced } \\
\text { features into one design }\end{array}$ & $\begin{array}{l}\text { Earlier design } \\
\text { approaches included } \\
\text { steam or electric } \\
\text { mechanisms }\end{array}$ & $\begin{array}{l}\text { More cylinders (earlier } \\
\text { models had } 2,4 \text {, or } 6 \\
\text { cylinders) arranged in } \\
\text { different ways }\end{array}$ & $\begin{array}{l}\text { Earlier designs had only } \\
\text { one head; sometimes } \\
\text { head was fixed }\end{array}$ & $\begin{array}{l}\text { Smaller tape, smaller } \\
\text { machine, longer recording } \\
\text { hours, cheaper price }\end{array}$ & & & & \\
\hline
\end{tabular}




\begin{tabular}{|c|c|c|c|c|c|c|c|c|}
\hline \multirow{3}{*}{$\begin{array}{l}\text { Authors, } \\
\text { Publication Date } \\
\text { Topic of Paper }\end{array}$} & \multicolumn{8}{|c|}{ Utterback and Suarez (1993) and Suarez and Utterback (1995) } \\
\hline & \multicolumn{8}{|c|}{ Firm entry and exit patterns before and after dominant design } \\
\hline & Technology 1 & Technology 2 & Technology 3 & Technology 4 & Technology 5 & Technology 6 & Technology 7 & Technology 8 \\
\hline Level of Analysis & Entire system & Entire system & Entire system & Subsystem & Subsystems & Subsystem & Entire system & Entire systems \\
\hline Product Description & Typewriters & Automobiles & TV sets & TV tubes & Transistors & Integrated circuit & Electronic calculator & Super-computer \\
\hline $\begin{array}{l}\text { Nature of } \\
\text { Technology }\end{array}$ & Stand-alone product & Stand-alone product & Component of system & $\begin{array}{l}\text { Component of } \\
\text { system }\end{array}$ & $\begin{array}{l}\text { Multipurpose } \\
\text { component of } \\
\text { system }\end{array}$ & $\begin{array}{l}\text { Multipurpose } \\
\text { component of } \\
\text { system }\end{array}$ & Stand-alone product & $\begin{array}{l}\text { Stand-alone } \\
\text { product }\end{array}$ \\
\hline $\begin{array}{l}\text { Technological } \\
\text { Context }\end{array}$ & Office equipment & $\begin{array}{l}\text { Infrastructure, network } \\
\text { of gas stations }\end{array}$ & TV system & TV screens & $\begin{array}{l}\text { Various electronic } \\
\text { systems }\end{array}$ & $\begin{array}{l}\text { Various electronic } \\
\text { systems }\end{array}$ & Calculating machine & \\
\hline \multicolumn{9}{|l|}{ Technology Measure } \\
\hline \multicolumn{9}{|l|}{$\begin{array}{l}\text { Market Share } \\
\text { Measure }\end{array}$} \\
\hline Level of Standard & Entire system & Subsystem & Subsystem & System & $\begin{array}{l}\text { Production } \\
\text { process systems }\end{array}$ & & System architecture & $\begin{array}{l}\text { System } \\
\text { architecture }\end{array}$ \\
\hline $\begin{array}{l}\text { Description of } \\
\text { Standard }\end{array}$ & $\begin{array}{l}\text { Underwood Model } 5 \text {, } \\
\text { Hess innovations }\end{array}$ & $\begin{array}{l}\text { All-steel; closed body } \\
\text { automobile }\end{array}$ & $\begin{array}{l}21 \text {-inch screen, RCA } \\
\text { technical standards }\end{array}$ & $\begin{array}{l}\text { All-glass, 21-inch } \\
\text { tube }\end{array}$ & Planar process & & Calculator on a chip & \\
\hline DD (Yes, No) & Yes & Yes & Yes & Yes & Yes & No & Yes & No \\
\hline \multicolumn{9}{|l|}{$\begin{array}{l}\text { Mechanism Creating } \\
\text { DD }\end{array}$} \\
\hline $\begin{array}{l}\text { Critical Dimensions } \\
\text { of Success }\end{array}$ & $\begin{array}{l}\text { Production costs and } \\
\text { ease of use }\end{array}$ & & & & $\begin{array}{l}\text { Manufacturing } \\
\text { cost and quality }\end{array}$ & & Cost & Cost and speed \\
\hline $\begin{array}{l}\text { Difference from } \\
\text { Earlier or Alternative } \\
\text { Designs }\end{array}$ & $\begin{array}{l}\text { Incorporates collection } \\
\text { of innovations } \\
\text { previously available } \\
\text { only individually }\end{array}$ & & & & & & $\begin{array}{l}\text { Reduction of } \\
\text { complexity, different } \\
\text { knowledge base }\end{array}$ & \\
\hline
\end{tabular}


Table 1 (Continued)

\begin{tabular}{|c|c|c|c|c|c|c|c|}
\hline $\begin{array}{l}\text { Authors, } \\
\text { Publication Date }\end{array}$ & $\begin{array}{l}\text { Henderson and } \\
\text { Clark (1990) }\end{array}$ & Henderson (1995) & $\begin{array}{l}\text { Rosenkopf and } \\
\text { Tushman (1993) }\end{array}$ & $\begin{array}{l}\text { Van de Ven and } \\
\text { Garud (1993) }\end{array}$ & $\begin{array}{l}\text { Khazam and Mowery } \\
\text { (1994) }\end{array}$ & \begin{tabular}{|l} 
Rosenbloom and \\
Christensen (1994)
\end{tabular} & $\begin{array}{l}\text { Christensen, Suárez, and } \\
\text { Utterback (1998) }\end{array}$ \\
\hline Topic of Paper & $\begin{array}{l}\text { Failure of } \\
\text { established firms }\end{array}$ & $\begin{array}{l}\text { Failure of technology life- } \\
\text { cycle concept as a } \\
\text { forecasting tool }\end{array}$ & $\begin{array}{l}\text { Co-evolution of } \\
\text { technology and } \\
\text { organization }\end{array}$ & \begin{tabular}{|l} 
Co-evolution of \\
technical and \\
institutional events at \\
micro level
\end{tabular} & $\begin{array}{l}\text { Strategies for creating } \\
\text { dominant designs }\end{array}$ & $\begin{array}{l}\text { Failure of incumbents to } \\
\text { pioneer technology that } \\
\text { serves new users and later } \\
\text { captures markets of old } \\
\text { users }\end{array}$ & $\begin{array}{l}\text { How time of entry in } \\
\text { industry life cycle affects } \\
\text { failure rates; market vs. } \\
\text { technological risks; only } \\
\text { architecturally dominant } \\
\text { designs have competitive } \\
\text { implications }\end{array}$ \\
\hline Level of Analysis & Entire system & Entire system & Subsystem & Entire system & Subsystem & Subsystem & Subsystem \\
\hline Product Description & $\begin{array}{l}\text { Photolithographic } \\
\text { aligners }\end{array}$ & $\begin{array}{l}\text { Photolithographic } \\
\text { aligners }\end{array}$ & Radio transmitters & $\begin{array}{l}\text { Cochlear implants } \\
\text { (hearing aids) }\end{array}$ & Chip architecture & Hard disc drives & Hard disc drives \\
\hline $\begin{array}{l}\text { Nature of } \\
\text { Technology }\end{array}$ & $\begin{array}{l}\text { Stand-alone product } \\
\text { in larger production } \\
\text { system }\end{array}$ & $\begin{array}{l}\text { Stand-alone product in } \\
\text { larger production } \\
\text { system }\end{array}$ & Component of system & Stand-alone product & Component of system & Component of system & Component of system \\
\hline $\begin{array}{l}\text { Technological } \\
\text { Context }\end{array}$ & $\begin{array}{l}\text { Manufacturing of } \\
\text { integrated circuits }\end{array}$ & $\begin{array}{l}\text { Manufacturing of } \\
\text { integrated circuits }\end{array}$ & Radio system & "Human ear" & $\begin{array}{l}\text { Workstation computer } \\
\text { systems }\end{array}$ & Computer systems & Computer systems \\
\hline $\begin{array}{l}\text { Technology } \\
\text { Measure }\end{array}$ & & $\begin{array}{l}\text { Minimum feature size of } \\
\text { smallest pattern } \\
\text { element it can transfer; } \\
\text { throughput; failure rate }\end{array}$ & & & & $\begin{array}{l}\text { Diameter of disc, capacity, } \\
\text { area density, access time }\end{array}$ & $\begin{array}{l}\text { Diameter of disc, speed of } \\
\text { pancake motor, intelligence } \\
\text { of controller }\end{array}$ \\
\hline $\begin{array}{l}\text { Market Share } \\
\text { Measure }\end{array}$ & $\begin{array}{l}\text { Sales revenue by } \\
\text { product, R\&D cost } \\
\text { per development } \\
\text { project }\end{array}$ & & & & & $\begin{array}{l}\text { Value of shipment of design } \\
\text { type by year, cumulative } \\
\text { shipment by design }\end{array}$ & $\begin{array}{l}\text { Percentage of models in a } \\
\text { given year that incorporate } \\
\text { five DD characteristics (see } \\
\text { below) }\end{array}$ \\
\hline Level of Standard & & $\begin{array}{l}\text { System architecture } \\
\text { (operational principle) }\end{array}$ & $\begin{array}{l}\text { Architecture of } \\
\text { subsystem }\end{array}$ & Architecture of system & $\begin{array}{l}\text { Overall chip } \\
\text { architecture }\end{array}$ & Architecture of subsystem & $\begin{array}{l}\text { Architecture of subsystem, } \\
\text { individual subsystem } \\
\text { components }\end{array}$ \\
\hline $\begin{array}{l}\text { Description of } \\
\text { Standard }\end{array}$ & & $\begin{array}{l}\text { Optical lithography } \\
\text { (using reflective or } \\
\text { refractive lenses) }\end{array}$ & $\begin{array}{l}\text { Vacuum tube } \\
\text { transmitters }\end{array}$ & Multichannel design & Sun's Spark chip & $\begin{array}{l}\text { IBM Winchester drives (14-, } \\
8-, 5.25-, 3.5-, 2.5 \text {-inch ) }\end{array}$ & $\begin{array}{l}\text { Winchester architecture, } \\
\text { pancake motor at spindle } \\
\text { base, voice coil accentuator } \\
\text { motor, rotary actuators, } \\
\text { intelligent drive electronics }\end{array}$ \\
\hline DD (Yes, No) & Not explicit & $\begin{array}{l}\text { Yes and No (author } \\
\text { uses the term but does } \\
\text { not use it as analytical } \\
\text { tool) }\end{array}$ & Yes & Yes & Yes & Yes & Yes \\
\hline $\begin{array}{l}\text { Mechanism } \\
\text { Creating DD }\end{array}$ & & $\begin{array}{l}\text { User needs, innovations } \\
\text { in components, and key } \\
\text { complementary } \\
\text { technologies }\end{array}$ & $\begin{array}{l}\text { Market selection and } \\
\text { government } \\
\text { involvement }\end{array}$ & \begin{tabular}{|l} 
Agreement by various \\
institutional actors, \\
market selection
\end{tabular} & Open system strategy & $\begin{array}{l}\text { Designs explored for new } \\
\text { users later on turn out to be } \\
\text { also superior for old users }\end{array}$ & $\begin{array}{l}\text { Better architecture } \\
\text { becomes apparent to } \\
\text { designers and later } \\
\text { adopted by all users }\end{array}$ \\
\hline $\begin{array}{l}\text { Critical Dimensions } \\
\text { of Success }\end{array}$ & $\begin{array}{l}\text { Precision, } \\
\text { throughput, failure } \\
\text { rate }\end{array}$ & $\begin{array}{l}\text { Investment decisions by } \\
\text { firms in particular } \\
\text { technology, unexpected } \\
\text { improvement in } \\
\text { component and } \\
\text { complementary } \\
\text { technologies }\end{array}$ & $\begin{array}{l}\text { Speech transmission, } \\
\text { level of fidelity }\end{array}$ & Speech discrimination & $\begin{array}{l}\text { Speed of processor, } \\
\text { development costs, } \\
\text { network externalities }\end{array}$ & $\begin{array}{l}\text { Storage capacity, size of } \\
\text { disc, cost, reliability }\end{array}$ & $\begin{array}{l}\text { Recording density, storage } \\
\text { capacity, size of disc, cost, } \\
\text { reliability }\end{array}$ \\
\hline $\begin{array}{l}\text { Difference from } \\
\text { Earlier or } \\
\text { Alternative Designs }\end{array}$ & $\begin{array}{l}\text { Reconfiguration of } \\
\text { linkages }\end{array}$ & $\begin{array}{l}\text { Reconfiguration of } \\
\text { linkages, alternative } \\
\text { designs: } x \text {-ray aligners } \\
\text { and electrobeam } \\
\text { aligners that use } \\
\text { different wave lengths }\end{array}$ & $\begin{array}{l}\text { Continuous instead of } \\
\text { discontinuous wave } \\
\text { transmission }\end{array}$ & \begin{tabular}{|l} 
Multiple electrodes \\
instead of single one
\end{tabular} & $\begin{array}{l}\text { Removes infrequently } \\
\text { used instructions to } \\
\text { reduce complexity }\end{array}$ & $\begin{array}{l}\text { Switch from removable disc } \\
\text { packs to fixed discs } \\
\text { (Winchester drive), then } \\
\text { successive changes in disc } \\
\text { diameter }\end{array}$ & $\begin{array}{l}\text { Switch from removable disc } \\
\text { packs to fixed discs, drive } \\
\text { motor relocated, control } \\
\text { subsystem added for much } \\
\text { better system performance }\end{array}$ \\
\hline
\end{tabular}




\begin{tabular}{|c|c|c|c|c|c|c|}
\hline $\begin{array}{l}\text { Authors, } \\
\text { Publication Date }\end{array}$ & Baum et al. (1995) & lansiti and Khana (1995) & $\begin{array}{l}\text { Sanderson and Uzumeri } \\
(1995)\end{array}$ & Miller et al. (1995) & Wade (1995) & |Islas (1999) \\
\hline Topic of Paper & $\begin{array}{l}\text { Dominant designs and firm } \\
\text { foundings and deaths }\end{array}$ & $\begin{array}{l}\text { Success of product } \\
\text { development processes }\end{array}$ & $\begin{array}{l}\text { Competitive strength based } \\
\text { on product families created by } \\
\text { changing interface only }\end{array}$ & $\begin{array}{l}\text { Innovation in low- } \\
\text { volume systems }\end{array}$ & $\begin{array}{l}\text { Evolution of technical } \\
\text { communities and } \\
\text { bandwagons creating } \\
\text { dominant designs }\end{array}$ & $\begin{array}{l}\text { Evolution of competing } \\
\text { technologies for power } \\
\text { generation, replacing earlier } \\
\text { design trajectory with new } \\
\text { one }\end{array}$ \\
\hline Level of Analysis & Entire system & $\begin{array}{l}\text { Entire system and } \\
\text { subsystems }\end{array}$ & Collection of systems & $\begin{array}{l}\text { Entire system and } \\
\text { subsystems }\end{array}$ & Subsystem & Subsystem \\
\hline Product Description & Facsimile machines & $\begin{array}{l}\text { Central processing unit of } \\
\text { mainframe computers }\end{array}$ & Walkmen & Flight simulators & Microprocessors & Gas turbine \\
\hline $\begin{array}{l}\text { Nature of } \\
\text { Technology }\end{array}$ & Network-dependent product & Component system & Stand-alone product & Stand-alone product & Component of systems & Component of systems \\
\hline $\begin{array}{l}\text { Technological } \\
\text { Context }\end{array}$ & Facsimile network & Mainframe computers & Personal electronics & Airplanes & $\begin{array}{l}\text { Personal computers and } \\
\text { workstations }\end{array}$ & Electric power system \\
\hline Technology Measure & $\begin{array}{l}\text { Compatible/non-compatible } \\
\text { designs }\end{array}$ & $\begin{array}{l}\text { MIPS (million instructions } \\
\text { per second) }\end{array}$ & $\begin{array}{l}\text { Existence or absence of } \\
\text { product feature }\end{array}$ & & & \\
\hline $\begin{array}{l}\text { Market Share } \\
\text { Measure }\end{array}$ & & & $\begin{array}{l}\text { US and Japanese market } \\
\text { share of personal stereo } \\
\text { equipment by firm }\end{array}$ & & $\begin{array}{l}\text { Installed base and new } \\
\text { sales (this is not a share } \\
\text { measure) }\end{array}$ & $\begin{array}{l}\text { Percentage of newly built } \\
\text { plants with gas turbines }\end{array}$ \\
\hline Level of Standard & Interface subsystem & System-level architecture & Collection of subsystems & Subsystems & $\begin{array}{l}\text { Architecture of } \\
\text { subsystem }\end{array}$ & Architecture of subsystem \\
\hline $\begin{array}{l}\text { Description of } \\
\text { Standard }\end{array}$ & Groups 1, 2, 3, 4 (standards) & $\begin{array}{l}\text { IBM } 360 \text { mainframe } \\
\text { architecture }\end{array}$ & $\begin{array}{l}\text { Sony's three platforms } \\
\text { underlying } 200 \text { Walkman } \\
\text { models }\end{array}$ & $\begin{array}{l}\text { Digital computing; six } \\
\text { degrees-of-freedom } \\
\text { motion }\end{array}$ & Intel-based processors & Combined cycle gas turbine \\
\hline DD (Yes, No) & Yes (by committee) & Yes & Yes & Yes & Yes & Yes \\
\hline $\begin{array}{l}\text { Mechanism Creating } \\
\text { DD }\end{array}$ & & & $\begin{array}{l}\text { Reconfiguration of existing } \\
\text { subsystem }\end{array}$ & $\begin{array}{l}\text { Standard-setting } \\
\text { bodies }\end{array}$ & $\begin{array}{l}\text { Bandwagons (small } \\
\text { events lock-in) }\end{array}$ & $\begin{array}{l}\text { The spreading of natural } \\
\text { gas as an source of energy } \\
\text { to many places, change in } \\
\text { legal environment, rise of } \\
\text { environmentalism }\end{array}$ \\
\hline $\begin{array}{l}\text { Critical Dimensions } \\
\text { of Success }\end{array}$ & Compatibility & $\begin{array}{l}\text { Compatibility with existing } \\
\text { software, speed }\end{array}$ & $\begin{array}{l}\text { Miniaturization, sound quality, } \\
\text { energy consumption }\end{array}$ & $\begin{array}{l}\text { Safety, cost, delivery } \\
\text { time }\end{array}$ & $\begin{array}{l}\text { Speed, cost, } \\
\text { compatibility }\end{array}$ & $\begin{array}{l}\text { Thermal efficiency, low unit } \\
\text { cost, availability of cheap } \\
\text { natural gas }\end{array}$ \\
\hline $\begin{array}{l}\text { Difference from } \\
\text { Earlier or Alternative } \\
\text { Designs }\end{array}$ & $\begin{array}{l}\text { From incompatible to } \\
\text { compatible products }\end{array}$ & $\begin{array}{l}\text { Different subsystem } \\
\text { architecture }\end{array}$ & $\begin{array}{l}\text { Improvement of old product } \\
\text { features and introduction of } \\
\text { new product features }\end{array}$ & $\begin{array}{l}\text { Novel approaches to } \\
\text { subsystems }\end{array}$ & $\begin{array}{l}\text { Higher speed and } \\
\text { density of circuits }\end{array}$ & $\begin{array}{l}\text { Steam turbine, piston } \\
\text { compressors, gas (petrol or } \\
\text { diesel) engines }\end{array}$ \\
\hline
\end{tabular}


Table 1 (Continued)

\begin{tabular}{|c|c|c|c|c|c|c|c|c|}
\hline $\begin{array}{l}\text { Authors, } \\
\text { Publication Date }\end{array}$ & Frenken, Saviotti, and Tromm & hetter (1999) & & & $\begin{array}{l}\text { Rosenkopf and Nerkar } \\
\text { (1999) }\end{array}$ & Burg and Kenney (2000) & $\begin{array}{l}\text { Hagedoorn, Carayannis, } \\
\text { and Alexander ( 2001) }\end{array}$ & $\begin{array}{l}\text { Hatfield, Tegarten, and } \\
\text { Echols (2001) }\end{array}$ \\
\hline Topic of Paper & Variety and standardization in & product classes; dominant des & signs existing only in product ni & iches & Component coevolution in & Role of venture capitalists & Formation & Hedging strategies \\
\hline & Technology 1 & Technology 2 & Technology 3 & Technology 4 & & & I & \\
\hline Level of Analysis & Entire system & Entire system & Entire system & Entire system & Subsystem & Subsystem & Entire system & Entire system \\
\hline Product Description & Aircraft & Helicopters & Motorcycles & Microcomputers & $\begin{array}{l}\text { Optical information } \\
\text { storage disk }\end{array}$ & Local Area Network (LAN) & PC computer & PC computer \\
\hline $\begin{array}{l}\text { Nature of } \\
\text { Technology }\end{array}$ & Stand-alone product & Stand-alone product & Stand-alone product & Multipurpose technology & $\begin{array}{l}\text { Component in larger } \\
\text { system }\end{array}$ & $\begin{array}{l}\text { Linking technology for large } \\
\text { number of computers }\end{array}$ & Multipurpose technology & $\begin{array}{l}\text { Multipurpose } \\
\text { technology }\end{array}$ \\
\hline $\begin{array}{l}\text { Technological } \\
\text { Context }\end{array}$ & $\begin{array}{l}\text { Transportation system, } \\
\text { airports }\end{array}$ & Heliports (often private) & Roads, gas stations & $\begin{array}{l}\text { Software, Internet, electrical } \\
\text { power system }\end{array}$ & $\begin{array}{l}\text { Music stereo and later } \\
\text { computers }\end{array}$ & Personal computing & Personal computing & Personal computing \\
\hline $\begin{array}{l}\text { Technology } \\
\text { Measure }\end{array}$ & $\begin{array}{l}\text { Discrete (e.g., engine type, } \\
\text { number of engines) and } \\
\text { continuous technological } \\
\text { characteristics (e.g., engine } \\
\text { power, range) }\end{array}$ & $\begin{array}{l}\text { Discrete (e.g., engine type, } \\
\text { number of engines) and } \\
\text { continuous technological } \\
\text { characteristics (e.g., engine } \\
\text { power, range) }\end{array}$ & $\begin{array}{l}\text { Discrete (e.g., engine type, } \\
\text { number of cylinders) and } \\
\text { continuous technological } \\
\text { characteristics (e.g., engine } \\
\text { power, volume, speed) }\end{array}$ & $\begin{array}{l}\text { Discrete (e.g., processor } \\
\text { type, operating system) and } \\
\text { continuous technological } \\
\text { characteristics (e.g., speed, } \\
\text { RAM, hard disc memory) }\end{array}$ & $\begin{array}{l}\text { Number of patents for } \\
\text { main components of } \\
\text { subsystems and their } \\
\text { cross-citations }\end{array}$ & & & \\
\hline $\begin{array}{l}\text { Market Share } \\
\text { Measure }\end{array}$ & $\begin{array}{l}\text { Relative frequency of } \\
\text { particular model in product } \\
\text { class }\end{array}$ & $\begin{array}{l}\text { Relative frequency of } \\
\text { particular model in product } \\
\text { class }\end{array}$ & $\begin{array}{l}\text { Relative frequency of } \\
\text { particular model in product } \\
\text { class }\end{array}$ & $\begin{array}{l}\text { Relative frequency of } \\
\text { particular model in product } \\
\text { class }\end{array}$ & $\begin{array}{l}\text { Market share of CD } \\
\text { players versus AHD and } \\
\text { MD optical discs }\end{array}$ & $\begin{array}{l}\text { Number of firms adopting and } \\
\text { developing a particular } \\
\text { standard }\end{array}$ & $\begin{array}{l}\text { Percentage of PCs } \\
\text { shipped with Wintel } \\
\text { technology }\end{array}$ & $\begin{array}{l}\text { Percentage of PCs } \\
\text { shipped with a certain } \\
\text { microprocessor }\end{array}$ \\
\hline $\begin{array}{l}\text { Level of Standard } \\
\text { Description of } \\
\text { Standard }\end{array}$ & Six discrete dimensions & $\begin{array}{l}\text { Five discrete dimensions } \\
\text { Two turboshaft engines, one } \\
\text { rotor helicopter }\end{array}$ & Three discrete dimensions & $\begin{array}{l}\text { Seven discrete dimensions } \\
\text { MS-DOS (later Wintel), hard } \\
\text { disc, CD ROM }\end{array}$ & $\begin{array}{l}\text { Subsystems level } \\
\text { CD optical disc system, } \\
\text { later DVD }\end{array}$ & $\begin{array}{l}\text { Subsystems level } \\
\text { Ethernet networking protocol }\end{array}$ & $\begin{array}{l}\text { Subsystems level } \\
\text { Wintel PC Platform }\end{array}$ & $\begin{array}{l}\text { Subsystems level } \\
\text { Intel micro-processsor }\end{array}$ \\
\hline DD (Yes, No) & $\begin{array}{l}\text { Only temporarily (1933- } \\
\text { 1942); otherwise increase in } \\
\text { variety because the product } \\
\text { category over time provides a } \\
\text { wider scope of services }\end{array}$ & Yes (decrease in variety) & $\begin{array}{l}\text { Only temporarily (1937- } \\
\text { 1949); otherwise increase in } \\
\text { variety because the product } \\
\text { category over time provides } \\
\text { a wider scope of services }\end{array}$ & Yes (decrease in variety) & Yes & Yes (mid-1980s) & Yes & Yes (1983) \\
\hline $\begin{array}{l}\text { Mechanism Creating } \\
\text { DD }\end{array}$ & $\begin{array}{r}\text { For all three technologies eco } \\
\text { leads to DD because su }\end{array}$ & $\begin{array}{l}\text { onomies of scale limited to a pa } \\
\text { uccessful firms scale their desi }\end{array}$ & $\begin{array}{l}\text { articular niche: Niche formation } \\
\text { ign to dominate the niche }\end{array}$ & $\begin{array}{l}\text { Network externalities } \\
\text { associated with compatible } \\
\text { designs }\end{array}$ & $\begin{array}{l}\text { 1. Coalitions of producers } \\
\text { and network externalities } \\
\text { 2. Negotiation among all } \\
\text { firms }\end{array}$ & $\begin{array}{l}\text { Open standard, early backing } \\
\text { of large incumbent firm } \\
\text { (DEC), slowness of IBM to } \\
\text { develop alternative } \\
\text { technology, bandwagon of } \\
\text { producers joining standard, } \\
\text { attracting U.S. venture } \\
\text { capital, network externalities }\end{array}$ & Network externalities & \\
\hline $\begin{array}{l}\text { Critical Dimensions } \\
\text { of Success }\end{array}$ & $\begin{array}{l}\text { Limiting competition in } \\
\text { product characteristics space }\end{array}$ & $\begin{array}{l}\text { Limiting competition in } \\
\text { product characteristics space }\end{array}$ & $\begin{array}{l}\text { Limiting competition in } \\
\text { product characteristics } \\
\text { space }\end{array}$ & Compatibility, price & $\begin{array}{l}\text { Fidelity of data and sound } \\
\text { reproduction, storage } \\
\text { capacity, compatibility }\end{array}$ & $\begin{array}{l}\text { Low cost, reliability, } \\
\text { transmission speed, great } \\
\text { improvement potential, } \\
\text { scalability }\end{array}$ & $\begin{array}{l}\text { Large installed base, } \\
\text { backward compatibility } \\
\text { with DOS, software } \\
\text { availability }\end{array}$ & \\
\hline $\begin{array}{l}\text { Difference from } \\
\text { Earlier or Alternative } \\
\text { Designs }\end{array}$ & & $\begin{array}{l}\text { Turboshaft engine instead of } \\
\text { alternative engines, one rotor } \\
\text { instead of two, two engines } \\
\text { instead of one }\end{array}$ & & $\begin{array}{l}\text { Earlier designs had many } \\
\text { different operating systems } \\
\text { and did not include CD-ROM, } \\
\text { color screen, and hard drives }\end{array}$ & $\begin{array}{l}\text { Earlier designs were } \\
\text { analog and not digital; } \\
\text { competing with } C D \\
\text { technology were AHD and } \\
\text { MD }\end{array}$ & $\begin{array}{l}\text { Ethernet (as well as the } \\
\text { second mover IBM's Token } \\
\text { Ring technology) was a non- } \\
\text { proprietary open standard, in } \\
\text { contrast to DECnet, ARCnet, } \\
\text { DOMAIN, Znet, Corvus, } \\
\text { Sytek }\end{array}$ & $\begin{array}{l}\text { OS/2, Mac, Osborne, } \\
\text { Tandy, Atari, } \\
\text { Commodore }\end{array}$ & \\
\hline
\end{tabular}


and market structures. Overcoming conceptual difficulties concerning the definition of a dominant design in complex technologies and the empirical verification of the existence of dominant designs also appears to be a precondition for addressing the alternative accounts offered to explain changes in market structures by such scholars as Gort and Klepper (1982), Klepper (1996, 2002) and Adner and Levinthal (2001).

For this reason the focus of the present essay is to solve some of the analytical and empirical puzzles surrounding the concept of a dominant design that have made it difficult for researchers to build a more cumulative research program. Our strategy is two-fold: building on Tushman and Murmann (1998), we first systemically review the literature on dominant designs to uncover the main conceptual problems. To extend further the insights of Tushman and Murmann (1998) and Baldwin and Clark (2000), we then propose a model that draws on complexity theory to arrive at a clear set of definitions about dominant designs. This allows us to discuss important implications of our model of technical change for industrial and organizational outcomes.

We conceptualize products as complex artifacts that evolve in the form of a nested hierarchy of technology cycles. Such a nested complex system perspective provides both unambiguous definitions of dominant designs (stable core components that can be stable interfaces) and inclusion of multiple levels of analysis (system, subsystem, component). We also incorporate more systematically into dominant design theory the idea of modularity in product architectures (Langlois and Robertson, 1992; Ulrich, 1995; Baldwin and Clark, 1997, 2000; Ethiraj and Levinthal, 2004). As a result, our complex system model of dominant designs can explain both why artifacts evolve as a nested hierarchy of technology cycles (Tushman and Murmann, 1998) and why multiple mechanisms can contribute towards the emergence of a dominant design. We believe our model will be a useful addition to the toolbox of scholars who study the relationship between technological and industrial change. It will equip researchers to collect the necessary empirical evidence to understand better how technological change is related to the changes in market structures. This will make it possible to assess in future studies the relative explanatory power of our model of dominant designs and rival explanations for the standardization of technologies.

The paper makes a number of specific contributions: in Section 2, we critically review the empirical literature on dominant designs with the objective of identifying commonalities and latent inconsistencies. While there is some degree of commonality in the core definition of a dominant design and in the underlying assumptions scholars make about technology, we find that there is significant inconsistency across studies with respect to the unit of analysis; the granularity or level of analysis; temporal sequencing; causal mechanisms; and boundaries within which the concept is applicable. (We explain these terms in more detail below.) It is heartening that such diverse studies tend to support some basic stylized facts: patterns of variation, selection and retention in technology and a classic "inverted-U" pattern of entry and exit in some industries. But the literature also presents anomalies that simple dominant design theory cannot resolve. First, how do we locate dominant designs in complex technological systems like telecommunications or health care? Second, is the emergence of a dominant design a cause or a consequence of industry evolution? Third, what is going on in such industries as computers, telecommunications, and possibly health care where the simple, inverted-U pattern of entry and exit does not seem to hold?

To address these and other issues, we believe it is necessary to expand and formalize the definition of a dominant design. For this purpose, in Section 3 we pull together, organize and synthesize ideas from a number of fields into a single, coherent definition of a dominant design. Our definition rests fundamentally on the concept of "nested hierarchies of design spaces." Search in these hierarchically organized, modular design spaces gives rise to "technology cycles," that is, episodes of variation, selection and retention in various parts of the complex technological system. The distinct design spaces that play host to "technology cycles," in turn, we argue, correspond to simple industries that can be expected to display the classic, inverted-U pattern of entry and exit.

We are certainly not the first ones to argue that complex technological systems are hierarchically organized. The idea has its roots in design theory going back to Simon (1962) and Alexander (1964). It appears in all theories of complex systems (e.g., Frenken et al., 1999a) and is central to the arguments of Baldwin and Clark (2000). In the literature on dominant designs the idea appears in Tushman and Rosenkopf (1992), Christensen and Rosenbloom (1995), and Tushman and Murmann (1998). We are building on and attempting to reconcile all this prior work.

But we go beyond the prior literature in a number of significant ways. First, we show how Polanyi's (1962) useful concept of an "operational principle" can be mapped onto the mathematically formal concept of "design spaces," used in design theory and search theory. We show how "operational principles" for different components of a complex technical system can 
be used to reveal the design hierarchy of that system. Second, building on this mapping, we operationalize Tushman and Rosenkopf's (1992) concepts of the "core" and "periphery" of a complex technological system on the basis of a so-called "pleiotropy map." Pleiotropy is a concept taken from biology, but, as we show, it can be applied to designs as well. Pleiotropy maps are related, but not identical to, the design structure matrices (DSMs) used in engineering and product development. We then propose to define "dominant design" as a set of designs that share the "high-pleiotropy" components of complex technical systems. Prior work in both design theory and evolutionary biology suggests that the high-pleiotropy components of a complex system are difficult (if not impossible) to change successfully. It follows immediately that the emergence of a widely accepted design with high-pleiotropy components will change the dynamics of design search and competition in the technological class. This idea, we argue, captures the essence of what scholars mean when they say "a dominant design has emerged" in some settings.

In Section 4, we investigate what our proposed definition implies for empirical studies of industry evolution. The hierarchical approach made operational by pleiotropy maps (or DSMs) makes it feasible to study the co-evolution of vertically related firms and industries. Large-sample studies of industry evolution heretofore have had to focus on "single layered" industries. Furthermore, a hierarchical approach to designs delivers different predictions about design search and industry dynamics in different parts of the technological hierarchy. Designs in some parts of the system may evolve very rapidly stimulating entry and creating turbulent industry dynamics, while designs in other parts remain stable. Our contribution is to propose a way to make this theoretical insight empirically testable. Pleiotropy maps are an operational concept: they can be constructed and tracked over time. We believe, when combined with our hierarchical definition of dominant design, such maps can be used to predict which members of a group of vertically related industries will exhibit rapid change and high turnover, and which will exhibit stability (though perhaps high growth) and low turnover.

\section{Variations in research on dominant design}

Since Abernathy (1978) and Abernathy and Utterback (1978) first developed the concept of a dominant design from a study of the automobile industry, many writers in the field of organization theory and strategy have found the concept an extremely useful tool for studying the evolution of technological products. Scholars who have empirically worked with the dominant design concept share the general view that technological change has a powerful and to some extent autonomous causal impact on the development of industries and firms. In the 1960s, economists such as Freeman (1968), Nelson (1962), and Rosenberg (1969) argued that to understand rate and direction of economic change it was not sufficient to look at the performance characteristics of technologies (or what Saviotti and Metcalfe, 1984, later called "service characteristics"); one also had to comprehend the inner workings of a technology (or what Saviotti and Metcalfe, 1984, called the "technical characteristics"). In this view, studies of the demand side for new technologies had to be enriched by studies of the supply side that would detail how technologies actually came about. The program of opening the economists' "black box" of technology found fertile ground at business schools, where scholars such as Abernathy and Utterback began detailed studies on how individual firms and particular industries would be shaped by technological forces that could not be predicted simply from knowledge of demand characteristics.

At the heart of dominant design thinking lies the empirical observation that technology evolves by trial and error and thus entails risks for the population of firms engaged in its development. When a new product class appears, it is very unclear what kind of inherent potential the technology possesses and what kind of needs its anticipated users will have. The only way to reduce the uncertainty about technological potential and user needs is to create different designs and receive feedback from users (Pinch and Bijker, 1984), on occasion by actively involving users in the product design process (Thomke and Hippel, 2002). Over time, only one or a few designs from the much larger number of design trials will eventually succeed. The firms that happen to be producers of the winning designs will flourish, whereas firms that invested in the failing designs will incur economic losses and may even go out of business.

Within this common framework, different scholars define a dominant design differently. But the key notions, traceable back to Abernathy and Utterback's seminal work, are two-fold: (1) a dominant design is widely adopted; and (2) the emergence of a dominant design apparently changes the nature of competition (within the corresponding industry). We emphasize apparently because, as discussed below, scholars differ on whether a dominant design is the cause or the consequence of changing competitive dynamics. Nevertheless, scholars agree that the competitive game among industry participants somehow changes around the time that the 
dominant design appears. Thus dominant designs are interesting (to both scholars and managers) because they signal a change in the nature of the game, with attendant winners and losers (Suarez, 2004).

A review of all the empirical dominant design studies we could find reveals that scholars have made a wide range of more specific discoveries about dominant designs. Taking different perspectives on the details of the dominant design phenomena, empirical researchers have produced a variety of findings. In our efforts to integrate these empirical observations into a sharper analytical framework, we found it useful to organize the different perspectives along the following six dimensions. Researchers differ in their work on dominant designs, namely in regard to: (i) the definition of dominant designs, (ii) the unit of analysis, (iii) the granularity (level) of analysis, (iv) the temporal sequencing of technological development, (v) the causal mechanisms, and (vi) the boundary conditions of the theory. These dimensions are, of course, not entirely independent from one another; the general conception of dominant designs directly affects how a particular researcher will think about how to take the various analytical steps required in theorizing and conducting empirical research on dominant designs. We believe that making the differences in the various approaches explicit constitutes an important step towards reconciling some of the conclusions in the literature on dominant design. Many findings that appear inconsistent at first glance can be integrated by making several important conceptual distinctions, which we will discuss in the pages that follow.

\subsection{Definitions of dominant designs}

Because Abernathy (1978) and Abernathy and Utterback (1978) pioneered the concept of a dominant design, we begin with their definition to provide a convenient reference point for discussing later definitions. These authors see a dominant design as the turning point that leads the industry to move from a system of "made-to-order" products to a standardized massmanufacturing system of a complex assembled product. According to Abernathy (1978), this transition from flexible to specialized production processes is marked by a series of steps. The first is the development of a model that has broader appeal in contrast to the design of earlier product variants that focused on performance dimensions valued by only a small number of users. This design that can satisfy the needs of a broad class of users is seen not as a radical innovation but rather a creative synthesis of innovations that were introduced independently in earlier products. The second step is the achievement of a dominant product design, one that attracts significant market share and forces imitative competition design reaction (Abernathy, 1978, p. 147). In the third step, competitors are forced to imitate this broadly appealing design (or alternatively to exit from the product market), thus inducing product standardization throughout the industry. Abernathy (1978) stipulates that a dominant design is one that diffuses almost completely through the industry (pp. 61-62).

Utterback and co-workers (Utterback and Suarez, 1993; Suarez and Utterback, 1995) have continued in this tradition, emphasizing that the emergence of a dominant design is a necessary precondition for one particular design to achieve a dominant market position. Anderson and Tushman (1990), by contrast, define a dominant design as "a single configuration or a narrow range of configurations that accounted for over $50 \%$ of new product sales or new process installations and maintained a $50 \%$ market share for at least 4 years" (p. 620). Anderson and Tushman (1990) differ from Utterback and Suarez (1993) in contending that a dominant design can only be known in retrospect and not in real time. For Henderson and Clark (1990, p. 14), a dominant design is characterized both by a set of core design concepts embodied in components that correspond to the major functions performed by the product and by a product architecture that defines the ways in which these components are integrated. Christensen et al. (1998) adopt this definition in their work on hard drives.

\subsection{Unit of analysis}

Starting with the early writings of Abernathy (1978) and Abernathy and Utterback (1978) on automobiles, scholars have argued that dominant designs are a phenomenon that occurs at the level of the entire product or, in the language that we develop later in detail, at the technological system level. (See again Table 1 for an analytic overview of all the empirical studies on dominant designs we have been able to find.) A dominant design at the product level has been identified for photographic aligners (Henderson and Clark, 1990; Henderson, 1995), container glass machines and flat glass machines (Anderson and Tushman, 1990), typewriters, electronic calculators, supercomputers (Utterback and Suarez, 1993; Suarez and Utterback, 1995), cochlear implant hearing aids (Van de Ven and Garud, 1993), walkmen (Sanderson and Uzumeri, 1995), helicopters and microcomputers (Frenken et al., 1999b).

But scholars have also analyzed dominant designs at the component level of a product (or the subsystems level). A dominant design at the subsystems 
level has been identified in the case of automobile engines (internal combustion engine; Abernathy, 1978), the configurations of cylinders of the internal combustion engines of automobiles (V-8 cylinder configuration; Abernathy, 1978), cement kilns and control unit of kilns (various kiln lengths and architectures of heating units, respectively; Anderson and Tushman, 1990), microprocessors of minicomputers (16-bit and core memory, 16-bit moss memory; Anderson and Tushman, 1990), transistors (planar process; Utterback and Suarez, 1993), radio transmitters (vacuum tube transmitters; Rosenkopf and Tushman, 1993), chip architecture of workstation computers (Sun's Spark chip; Khazam and Mowery, 1994), microprocessors (Intelbased processors; Wade, 1995, Hatfield et al., 2001), hard drives (the Winchester architecture; Christensen et al., 1998), gas turbines (combined cycle turbines; Islas, 1999), optical information storage discs (CD, later DVD; Rosenkopf and Nerkar, 1999), and local area networks (LAN) for computers (Ethernet; Burg and Von Kenney, 2000).

Our analysis of the empirical literature on dominant designs also shows that researchers have sometimes conducted studies spanning different levels of analysis (system and subsystem levels) and then identified a dominant design by pointing to individual subsystem. Rosenbloom and Cusumano (1987) researched videocassette recorders and found a dominant design at the reading and recording subsystem (the two-head rotating scanner); later, Cusumano et al. (1992) identified a dominant design in the tape format (VHS) of videocassette recorders (for details on these studies, see Table 1). Iansiti and Khanna (1995) studied the evolution of mainframe computers and located a dominant design in the core subsystem of the technology, the central processing unit. Miller et al. (1995) investigated the entire system of flight simulators and identified a dominant design at the subsystem level, described as digital computing and six-degrees-of-freedom motion. Sanderson and Uzumeri (1995) analyzed Walkman personal stereo systems and found that 200 Sony models were based on three platforms, each of which represented a collection of particular components that were spatially arranged and enclosed in different ways. Baum et al. (1995) have argued for a dominant design in fax machines by giving evidence about the standardization of how fax machines communicated with one another (the linking interface subsystem). Utterback and Suarez (1993) also suggested that a dominant design emerged in a product class while pointing to a dominant design at a lower level of the system (all-steel closed body in cars, and all-glass, 21-in. tube in TV sets).

\subsection{Granularity (level) of analysis}

The preceding discussion highlights differences in the units of analysis (the overall system, multiple levels of subsystems, and components). But scholars also operate at different levels of abstraction. When Abernathy (1978) analyzes, for example, how the internal combustion engine beat the steam and electric engine to become the dominant design for the motor unit in 1902, he is identifying a dominant design at the abstract level of an operational principle for an engine. When he later determines that the V-8 internal combustion engine became the dominant design in the 1930s, he is operating at a lower level of abstraction. Whereas the first identification of a dominant design is based on a relatively general criterion that distinguishes between fundamentally different technological principles for creating motive power-combustion, steam, electricity-the second judgment is based on a much more specific criterion that distinguishes between different designs within the combustion approach.

To put this diagnosis in abstract terms, empirical research on dominant designs requires a judgment about whether two designs are different or the same. The outcome of these judgments depends crucially on the level of resolution or granularity one brings to the analysis. Two distinct dimensions of granularity are relevant in this context: the level of detail at which the artifact is examined and the granularity of the time interval used for measuring the dynamics of technical change. At the most detailed level of analysis, no two artifacts are the same; at the coarsest level of analysis, every two artifacts are the same. In addition, using a very small time interval for recording observations (e.g., milliseconds) a technology will never display any change in its design from one interval to the next because human designers operate at longer time scales. Using a very long interval for recording observations (e.g., 1000 years) a technology is likely to display so much change that one can never speak meaningfully about the emergence of any kind of standardization. Moreover, such a coarse time resolution misses entire classes of technology for which the full life span is shorter than 1000 years. Competitive dynamics in industries play themselves out on the time scale of days, weeks, months, quarters, years, and decades. And in many instances, judgments about whether a dominant design has emerged within a product class will be sensitive to whether one has picked one time scale in the range or another one. To date, research on dominant designs has not fully recognized this problem. We believe that, to make studies comparable, it is important to be explicit about the time interval used for measurement. 


\subsection{Temporal sequencing}

In the original formulation of dominant designs, Abernathy and Utterback (1978) suggest that dominant designs emerge once in the evolution of a particular product class. Similarly, in all the seven product classes Suarez and Utterback (1995) examine, dominant designs emerge once and continue to exist for as long as the product class continues to find customers in the market place. Other scholars have argued that the evolution of product classes is marked by recurring technological discontinuities followed by the emergence of a new dominant design (see for example, Anderson and Tushman, 1990; Henderson and Clark, 1990; and Sanderson and Uzumeri, 1995). Whether or not a technology does indeed change through a cyclical process marked by a technological discontinuity, an era of ferment (variation), the selection of a dominant design, and an era of incremental innovation (retention) broken once again by a technological discontinuity is an important question far beyond the discipline of technology studies. It is particularly important for the study of industrial dynamics because technological discontinuities have competencedestroying effects on incumbent firms and thus lower the barriers to entry for new firms (Anderson and Tushman, 1990).

\subsection{Causal mechanisms}

Scholars of dominant designs have appealed to a variety of underlying causal logics to explain why a particular design approach rather than other ones emerges as the dominant design. They can be classified into five types.

a. Abernathy and Utterback (1978), and later Utterback and Suarez (1993, 1995) and Christensen et al. (1998), emphasize that a dominant design becomes dominant because it represents the best technological compromise among the different functional characteristics of the technology, forcing all other producers to imitate the design if they want to win customers. In this type of explanation a dominant design is a cause that settles debates among designers and subsequently the search for improvement a technology is guided by the dominant design.

b. A second and one of the most straightforward explanations for the emergence of a dominant design are economies of scale that can be realized with standardized products (Klepper, 1997; Hounshell, 1984). On this economic logic, the design among many competing designs that initially acquires a lead in market share will emerge as the dominant design. ${ }^{2}$ Here a dominant design is a consequence of a first mover advantage.

c. A similar logic is followed by scholars who view network externalities as a strong force behind the selection of a particular design approach as the dominant one (e.g., Wade, 1995; Baum et al., 1995; Rosenkopf and Nerkar, 1999; Frenken et al., 1999b; Hagedoorn et al., 2001). The concept of network externalities describes a situation where the value of adopting a particular technology depends on the number of users who have purchased a compatible technology (David, 1985; Arthur, 1989). Telephone systems, fax machines, ATM networks, VCRs, and computer platforms are all examples in which users have a strong incentive to adopt the technology that is already adopted by many other users because the larger network will make the particular technology more valuable to the individual user. Economies of scale and network externalities are two conditions that create dynamic increasing returns. Random factors may allow one design to take an initial lead, but subsequently without a major additional random shock (everything else being equal) the design with the small lead will inexorably win a dominant position because higher returns can be achieved with it. In this type of explanation a dominant design is similarly a consequence of a first mover advantage.

d. Firms often realize that the design initially gaining the lead in market share will often become the dominant design because of these self-reinforcing processes. Some scholars have therefore emphasized strategic maneuvering on the part of firms as the explanation for the emergence of particular dominant designs. These strategies include coalitions, R\&D collaborations, pricing, and licensing (Cusumano et al., 1992; Liebowitz and Margolis, 1995; Khazam and Mowery, 1994). For example, Cusumano et al. (1992) and Liebowitz and Margolis (1995) cite JVC's strategy of licensing their VHS design to many other electronic companies as the main reason why the firm was able to beat Sony's Betamax design, even though Sony had been first to market. In the strategic maneuvering type of explanation a dominant design is treated more as a consequence than a cause.

\footnotetext{
${ }^{2}$ Klepper $(1996,2002)$ puts the emphasis on learning to do R\&D rather than scale economies, which explains why early and more experienced entrants significantly more often survive a shake-out than do late entrants and less experienced entrants.
} 
e. A fifth line of research emphasizes that, contrary to simple products, the multidimensional nature and high development costs of many complex products make it less probable that dominant designs are selected through market competition. Scholars in this tradition contend that dominant designs emerge through a combination of sociological, political, and organizational dynamics. For machine tools, electricity networks, radio transmitters (Tushman and Rosenkopf, 1992); nuclear power stations (Cowan, 1990); and flight simulators (Miller et al., 1995), dominant designs emerged through negotiations involving a diverse set of actors with a stake in the technology. Consistent with this sociological and political logic, Chesbrough (1999) showed for the case of hard drives how differences in institutional environments of various European countries, the U.S., and Japan affected the technological and industrial dynamics. The causality in this type of explanation is not easy to identify. The actors in these processes are often exquisitely attuned to the technological tradeoffs and compromises embedded in different candidate designs.

\subsection{Boundary conditions}

Researchers of dominant designs have taken a variety of positions on the range of phenomena dominant design theory is made to explain. Anderson and Tushman (1990) take the broadest perspective. For them, dominant design theory applies to the evolution of all technologies that are free from patent interference: as long as the normal competitive forces are allowed to shape the development of technology, dominant designs can be expected to emerge. Abernathy and Utterback (1978) limited the range of phenomena this theory was designed to explain to only industries characterized by a highly complex production process in which multiple inputs are combined to a highly valued product, the characteristics of which may be varied. Abernathy and Utterback put particular emphasis on the requirement that it must be possible to make a final product in a variety of ways, which therefore would allow firms to differentiate the product along a number of dimensions. The authors also speculate that the concept of a dominant design might be useful in the communication industry and in certain health care services (p. 84). More recently, Utterback and Suarez seem to confine dominant design theory to the manufacturing sector (1993), and in their later paper (Suarez and Utterback, 1995) appear to restrict the theory to complex assembled products. For Teece (1986) and Windrum and Birchenhall (1998), dominant design theory is limited to mass markets, where consumer tastes are relatively homogeneous. Although Nelson (1995) also stresses uniformity of consumer demand as a condition for the emergence of dominant designs, he does not express the idea that dominant design theory applies only to mass markets. However, in his view, the theory of empirical validity is limited to complex, systemic technologies.

In addition to evaluating what designs count as the same and what designs count as different, all empirical researchers of dominant designs have made some implicit judgment about which designs fall within the same class in which a dominant design emerges or which do not. As Baldwin and Clark (2000, p. 24) point out, "in the minds of human beings, artifact classes are subjective and informal, and their boundaries depend on both perception and natural language. As a result, the boundaries often seem fuzzy and arbitrary." Empirical researchers have handled this problem of identifying the boundaries of a design class quite well by mostly picking user segments that have a great deal of face validity because they follow widely shared definitions of markets. But the problem with taking a class as given is that technologies change or destroy the boundaries of markets. Often, new technologies are developed for a particular market and then turn out to be useful for another application and they therefore diffuse into other uses (computers are a prime example in this regards). Or technologies developed for a niche of market improve so much that they can beat the technologies in the center of market (Christensen and Rosenbloom, 1995). We believe a technologicallybased criterion to demarcate classes and designs will help make empirical research on dominant designs even more powerful.

\section{Useful concepts for research on dominant designs}

Given the wide range of contributions discussed in the previous section, we are convinced that at this stage in the development of dominant design theory a more formalized approach is both possible and necessary. Such an approach should develop a more systematic understanding of technological design in general and deal explicitly with the six dimensions of differences (disagreements) in the literature discussed above. Our more formalized approach builds on what we regard as the best ideas developed by scholars from a variety of disciplines over the past 40 years. The model of a dominant design we propose applies complex systems theory to technological artifacts. Following the work of Simon (1969 [1996], p. 4) on the evolution of complex systems, we define a technology as a man-made system that is constructed from 
components that function collectively to produce a number of functions for users. Our model of technology as a complex multilayered system incorporates such important concepts as operational principle, design space, and core and periphery. In our view, a complex systems perspective provides: (i) a less ad-hoc definition of what constitutes a dominant design, as well as a more systematic understanding of and predictions concerning, (ii) the unit of analysis, (iii) the granularity of analysis, (iv) the cyclical nature of technological development, (v) the causal mechanisms, and (vi) the boundary conditions of the theory.

The first thing we will do is lay out the ideas on which we will build our formal approach. These are the notions of technology as a complex system; composed of subsystems and components; the operational principle; core and peripheral components; economies of scope; and radical versus incremental innovations. Then we will describe our proposed hierarchical definition of dominant designs, and indicate how it can be operationalized using the concepts and methods we articulated earlier.

\subsection{Technology as a complex system}

Although an increasing number of scholars have recently stressed the complex nature of technological artifacts and the importance of recognizing this feature in analyses of technical change, the complex systems perspective to technology clearly goes back a long time. Simon $(1962,1969)$ and Alexander (1964) introduced this perspective to the analysis of technological design and technical change. Both scholars explained the difficulties and inherent uncertainties of designing properly functioning artifacts by making reference to what was already known about complex systems: small changes in design may have large, disruptive consequences for the functioning of the complete artifact.

Later historians Rosenberg (1969), David (1975), and Hughes (1983) stressed that the incremental trajectorylike nature of technological development is primarily the result of interdependencies among parts in a complex artifact. Interdependencies, or "technical imbalances", imply that some parts of an artifact cannot be improved without making accompanying innovations in other parts. This means that technical change in complex artifacts is typically localized in the sense that changes are tried in one part, and when a new solution is accepted, this defines further problems in other parts, which in turn may define new problems in other parts (later, people started calling these trajectories path-dependent). This incremental and sequential pattern of problem solving, first described systematically by Rosenberg (1969), dif- fers from more radical strategies that involve simultaneous changes in many parts of the system. That the latter strategy is rarely successful is easily shown. Changing many parts in a complex artifact is a long shot for success: computational experiments have demonstrated that the probability of a successful innovation in complex systems with high interdependency is inversely related to the number of parts or dimensions that are changed simultaneously (Frenken et al., 1999a; Kauffman et al., 2000).

Interdependencies also imply that changing prices of particular parts of the artifact (e.g., the fuel) need not lead to factor substitution because the benefits from substituting the technology of one part of an artifact may be offset by the technical imbalances, and hence extra costs, that factor substitution generates in other parts of the system. This means that when new component technology that is less costly or better performing becomes available, it is not automatically adopted because it may not fit well with the other components in a system Mokyr (2002, pp. 229-231). High degrees of interdependence across a system's parts thus explain the high degree of irreversibility of technological development in complex artifacts. These lines of thought were picked up and further developed by Abernathy and Utterback (1978), Nelson and Winter (1977), Dosi (1982), and Sahal (1985), who introduced the concepts of dominant designs, natural trajectories, technological paradigms, and technological guideposts.

Synopsis 1. In complex artifacts, technological development is a local, sequential, and irreversible search process that is, to a large extent, insensitive to changes in factor prices of component technologies.

\subsection{System, subsystems, and components}

In his famous article on the architecture of complexity, Simon (1962) pointed out that artifacts, like other complex systems, are not just made up of elementary components, all directly interacting with one another, but rather consist of a nested hierarchy of subsystems. Simon and more recent scholars of modularity in design (Langlois and Robertson, 1992; Ulrich, 1995; Sanchez and Mahoney, 1996; Frenken et al., 1999a; Schilling, 2000; Baldwin and Clark, 2000; Simon, 2002; Ethiraj and Levinthal, 2004) have highlighted that the vast majority of technical systems are nearly decomposable in the sense that the high-frequency interactions tend to occur within subsystems and the low-frequency interactions occur across subsystems. The crucial conceptual point that empirical research on dominant designs has not sufficiently paid attention to in collecting empirical 
Table 2

Henderson and Clark's (1990) innovation framework

\begin{tabular}{lll}
\hline Linkages between core & Core concepts & \\
\cline { 2 - 3 } concepts and components & Reinforced & Overturned \\
\hline Unchanged & Incremental & $\begin{array}{l}\text { Modular } \\
\text { innovation }\end{array}$ \\
Changed & innovation & Radical \\
& Architectural & innovation \\
\hline
\end{tabular}

evidence is that most technologies have multiple levels of subsystems that are organized in a hierarchical fashion (Tushman and Murmann, 1998). In terms of Henderson and Clark's innovation framework (see Table 2), which distinguishes between incremental, modular, architectural, and radical innovations, the hierarchical structure of systems has an important implication: a modular innovation at one level in the hierarchy can clearly be an architectural or radical innovation at a lower level in the hierarchy.

In their landmark book Design Rules, Baldwin and Clark (2000, p. 94) provide a very useful overview of all of the different hierarchies that exist in the context of the technical and industrial structures that produce them. The task structure, the design structure, and the artifact structure, as well as the contract structures that relate economic actors to one another, all have a hierarchical organization in order to make complexity manageable for human beings. For complex human-made artifacts to be created in the first place and possess the potential for improvement, there is simply no other way than to create quasi-independent subsystems of the artifact that can be improved upon in parallel.

We think one additional distinction is absolutely essential to understanding the technological characteristics of an artifact. Complex technological artifacts such as an airplane can be described in terms of two kinds of hierarchies: a hierarchy of inclusion and a hierarchy of control (Wilson, 1969). ${ }^{3}$

First, artifacts are structured in terms of a hierarchy of nested parts (see Fig. 1). An entire airplane is made up of a fuselage, wings, propelling device, and landing gear, which can be represented as first-order subsystems. Each of these first-order subsystems has potentially included within it smaller second-order subsystems, and potentially many further levels of ever-smaller subsystems until the level of the fundamental or basic components is

\footnotetext{
${ }^{3}$ Both the notions of a hierarchy of inclusion and a hierarchy of control embody the most general notion of hierarchy as an asymmetrical relationship between entities.
}

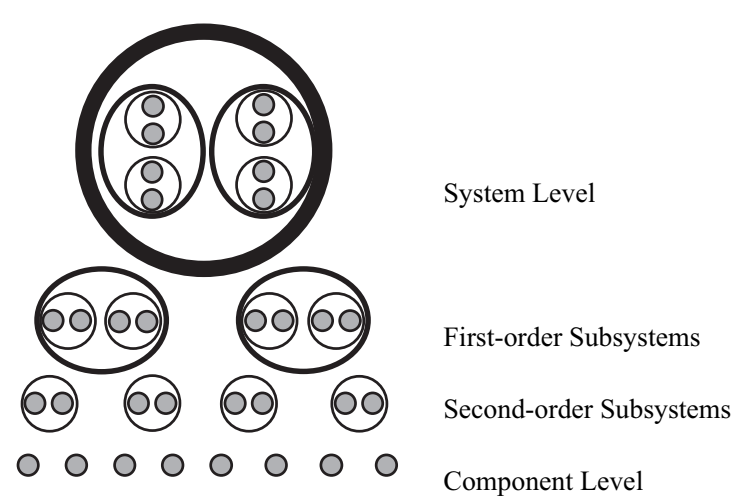

Fig. 1. Illustration of a four-level nested hierarchy.

reached. In the case of an airplane, its wing subsystems contain within flaps, fuel tanks, lights, etc. The flaps, in turn, are composed of steering flaps and breaking flaps. Flaps have a lattice and a skin and are held together by flush rivets (for details of this example, see Tushman and Murmann, 1998). Each level in the artifact hierarchy can go through its own technology cycle marked by the processes of variation, selection, and retention.

Second, complex artifacts are also structured in terms of a hierarchy of control. The different functional parts of an airplane are subordinated to one or few subsystems that control how all other the first-order subsystems interact to form a well-functioning system. Operating systems in computers and the brain in the human body are examples of subsystems that control all other subsystems in their respective systems. Each subsystem, in turn, tends to have a component that controls the other components within the subsystem. At any level, a discontinuity in such a "core" component starts a new technology cycle.

Finally, when mapping out the structure of complex systems, it is useful to keep in mind that systems can be small or large in two senses. They can have few or many levels of subsystems (flat hierarchies versus tall hierarchies). At the same time, within each level they can be homogeneous (the first-order subsystems are of the same kind, e.g., many computers connected together into a network) or heterogeneous (e.g., the many different pieces of equipment in a plant that form a long assembly line).

Synopsis 2. Complex artifacts are organized in terms of a nested hierarchy of subsystems, which undergo technology cycles marked by the processes of variation, selection, and retention.

\subsection{Operational principle}

We saw earlier that empirical researchers on dominant designs always face the question of whether two 
designs are the same or different. A similar question that arises in defining technologies as complex systems is how one decides when two artifacts belong to the same class of complex artifacts. Obviously, both aircraft and helicopters are prime examples of complex artifacts, but should their evolution (e.g., in terms of the emergence of a dominant design) be analyzed together? Without delineation, any conceptualization of a dominant design is impossible, because dominance can only be established with reference to a distribution of artifacts that belong to a technological class. We believe the concept of an operational principle is a very useful tool for classifying artifacts into classes. This concept, originally developed by Polanyi (1962) in the context of developing a theory of how human beings know things, was later used in Vincenti's writings on the history of airplanes (1990, 1991, 1994). For Polanyi, an operational principle captures the kind of knowledge a human designer must have in order to build a technological device that works on the physical world in a desired way. 'In a desired way' means fulfilling a basic user need such as "transporting goods and people through air." To put it differently, an operational principle defines how the parts interact with one another to implement the goal of overall technology.

Consider the example of the principle underlying the first successful human flight. Instead of trying to design a flying machine with flapping wings to provide both the counterforce to gravity and forward thrust, in 1809 , Cawley (Vincenti, 1990) proposed to separate lift from propulsion by using a fixed wing and propelling it forward with motor power. The central idea was that moving a rigid surface through resisting air would provide the upward force countering gravity. As Vincenti has noted, this was a radically different way to conceptualize the design of an airplane because it freed designers from the impractical idea of flapping wings. Subsequently, the fixed-wing and forward propulsion idea became the operational principle underlying all airplane designs.

When human beings have grasped the operational principle of a technology, they know how an artifact can act on nature in a special beneficial way. Because an operational principle essentially specifies how components need to be arranged in order to create a successful artifact, operational principles reveal the abstract logic of how an artifact works and thus provide the starting point for understanding what the essential aspects of a particular technology are. Saviotti and Metcalfe (1984) have argued that to analyze technological evolution it is important to ascertain the technical characteristics of an artifact, which they define as the key dimensions of a technology. In fact, the operational principle of an artifact sets out the relevant dimensions of what we will later call the design space of an artifact. For the researchers of technological change this means that once the operational principle of an artifact has been determined, this automatically decides the key technical dimensions of an artifact and thus determines in what dimensions two artifacts can differ technically without belonging to different classes of technology.

In using the concept of an operational principle, one is able to compare different technologies by probing whether they work according to the same the operational principle or not. For instance, planes and helicopters, both devices for air travel, differ in terms of how they achieve the general task of transporting humans in the air. A plane accomplishes flight by separating the propelling function and the lifting function into two separate components (the propeller or jet and the wings), whereas the helicopter realizes movement in the air by implementing the lifting and propelling function in one and the same component, the large vertical rotor. Rockets, another class of devices for traveling, make air travel possible by allowing an expanding air-fuel mix to escape only through the rear of the device and thus propel it forward. Rocket propulsion requires neither wings nor propellers.

Operational principles allow the student of technology to categorize a set of artifacts into general product classes. This is useful for research on dominant designs by making it possible to distinguish between variation within a product class that shares the same operational principle from variation between product classes that are characterized by different operational principles.

Synopsis 3. To organize the universe of all technological artifacts into general product categories, the operational principle of the artifact is a useful classification criterion.

Within a product class, subclasses can be defined by distinguishing between the different operational principles used in different subsystems. More generally, designers distinguish between different design dimensions of an artifact, or its "technical characteristics". Because different solutions are possible along each dimension, many combinations of solutions are possible to construct one and the same type of artifact. The total set of designs that can be constructed out of all possible combinations of alternative choices along its dimensions is called an artifact's design space (Dennett, 1995; Baldwin and Clark, 2000). Consider, for example, Bradshaw's (1992) reconstruction of the design space for gliders alone, as faced by the Wright Brothers at the turn of the nineteenth century (see Table 3 ). Though only a 
Table 3

The dimensions of the design space of early gliders (Bradshaw, 1992)

\begin{tabular}{ll}
\hline Technical characteristics & Variants explored by early researchers \\
\hline Number of wings & $1-80$ \\
Wing configuration & Monoplane, biplane, triplane \\
Wing placement & Stacked, tandem, staggered \\
Wing angle & Anhedral, flat wing, staggered \\
Camber of wings & $1 / 10,1 / 15,1 / 12,1 / 8,1 / 6$ \\
Wingspan & Twenty different sizes between $6^{\prime}$ and 104' \\
Chord & Five different sizes between $3^{\prime}$ and $10^{\prime}$ \\
Shape of wings & Bird-like, rectangular, bat-like, insect-like \\
Tail placement & Forward (canard), rear, mid
\end{tabular}

$80 \times 3 \times 3 \times 3 \times 5 \times 20 \times 5 \times 4 \times 3=12,960,000$ different designs.

relatively small number of dimensions/components are distinguished (9), the number of possible designs is enormous $(12,960,000)$.

The example of the three technology classes enabling air travel also serves to demonstrate a second feature of complex artifacts that we discussed earlier: hierarchical structure. Devices to travel through air are classified as aircraft, helicopters, rockets, and others. Within the class of aircraft, one can distinguish between propeller aircraft and jet aircraft. In propeller aircraft, one can distinguish between piston propeller and turbopropeller, and so forth. Complex systems typically consist of components that are themselves complex systems. As a result, one can conceptualize complex artifacts as a nested hierarchy of design spaces. This hierarchical view of dominant designs implies that there can, in fact, be dominant designs at a higher (more encompassing) level without there being any dominant design at the lower level. All that is required is that the operational principles-i.e., the way lower-level subsystems are combined into a system through a set of standard design rules-be dominant across the industry (see Baldwin and Clark, 2000, for a superb articulation of the idea of design rules).

Synopsis 4. To classify artifacts within a product class, one can use the operational principles of the artifact's subsystems, starting with the first-order subsystems all the way to the lowest level subsystems.

\subsection{Core and periphery}

Imagine a population of designs that are exactly the same in all dimensions of the design space represented in Table 3, except for one dimension. Would this qualify as a dominant design? To state that a dominant design is present in, say, aircraft, when all aircraft share the same design for all their components, would count as a very stringent requirement that never would be met in practice. The history of technological innovation shows that, over time, design converges in some dimensions yet differentiates in others. One solution to this definitional problem discussed earlier is to argue that dominant designs can only be assessed at the level of a single component (subsystem), e.g., the standardization of the scanning head of VCRs analyzed by Rosenbloom and Cusumano (1987). However, given the hierarchical nature of complex technological artifacts, the shift of analysis from the artifact to its first-level subsystem also shifts the problem of defining a dominant design to that next level. Given that a scanning head consists of many technical dimensions, when does one speak of a dominant design of scanning heads? Which dimensions need to be standardized before one can speak of a dominant design?

We have come to the conclusion that the answer to this question lies in the notion of distinguishing the core and peripheral components of any design. To define core and periphery in complex artifacts, the concept of pleiotropy from biology provides analytic sharpness. In biology, researchers distinguish between the genotype, the level at which mutation occurs (genes), and the phenotype, the level at which differential success of organisms becomes apparent (traits). The number of traits affected by a particular gene in the genotype is referred to as a gene's "pleiotropy" (Matthews, 1984; Altenberg, 1995). The concept of pleiotropy in biology has been of great importance to the understanding of evolution in that a mutation in a gene of high pleiotropy has a much lower probability of success than a mutation in a gene with low pleiotropy. ${ }^{4}$ The probability that a mutation will increase fitness depends inversely on the pleiotropy of the gene in which the mutation occurs. A mutation in a gene with high pleiotropy means that the fitness values of many traits are assigned new values, the joint net effect of which is unlikely to be advantageous, whereas a mutation in a gene with low pleiotropy implies that only few traits are assigned new fitness values.

Analogous to the biological model, technical characteristics (the components) make up the "genotype" of a product technology, and service characteristics (the product attributes) make up the "phenotype" of a technology (Saviotti and Metcalfe, 1984). Technical characteristics are manipulated by designers ("mutation"), and service characteristics determine the usefulness of

\footnotetext{
${ }^{4}$ This was formally proved by Altenberg (1995), using a generalized version of Kauffman's (1993) NK-model. See also Frenken (2001, 2006).
} 
(a)

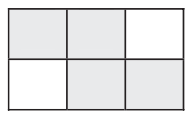

(b)

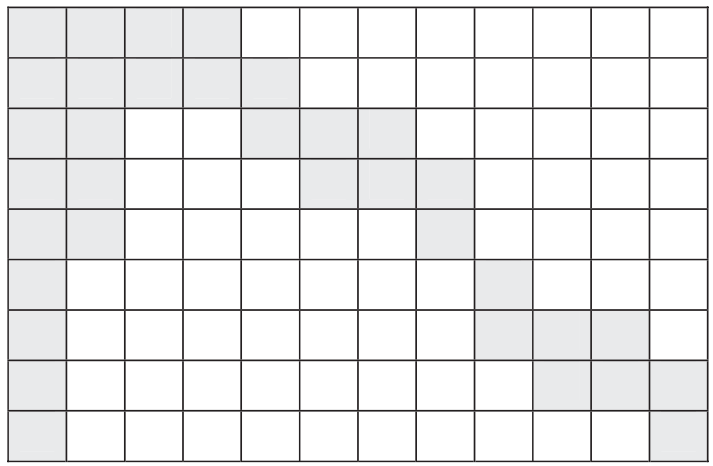

Fig. 2. (a) Example of a genotype-phenotype map with two product service characteristics (rows) and three technical characteristics (columns). (b) Example of a genotype-phenotype map with 9 services characteristics (rows) and 12 technical characteristics (columns). Column 1 is an interface standard with a pleiotropy of 9 . Column 2 is a core component with a pleiotropy of 5 . All other components are peripheral with a pleiotropy of 2 .

an artifact in the eyes of users ("fitness"). ${ }^{5}$ Again, one can define the pleiotropy of a component in a technical artifact by the number of functions affected by this component-meaning the number of service characteristics that will change their value when this component in the system is changed (Frenken, 2001, 2006). The set of pleiotropy relations between technical characteristics and service characteristics constitute an important part of the system's architecture. Henderson and Clark's (1990) definition of an architectural innovation as a reconfiguration of existing components amounts precisely to a change in the pleiotropy relation between components and attributes without a change in the components themselves.

An architecture of a complex system can be represented by a matrix specifying the relations between technical characteristics (the components) and service characteristics (product attributes) (Altenberg, 1994, 1995; Saviotti and Metcalfe, 1984). Fig. 2a shows an architecture with three technical characteristics as columns (say, type of engine, type of tires, type of steering device) and two service characteristics as rows (say, speed and safety). The figure shows two characteristics with pleiotropy equal to one and one characteristic

\footnotetext{
5 This distinction between the technical and service characteristics of a technology is similar to the distinction made by Baldwin and Clark (2000) between design elements and product functions.
}

with pleiotropy equal to two. The probability of a performance increase in speed or safety is greater for a change in the characteristic with a pleiotropy of one than for a change in a characteristic with a pleiotropy of two: a change in the latter may improve one service characteristic, but this increase may well be entirely offset by lower performance in the other service characteristic. The risk of a net loss becomes greater for components with higher pleiotropy; i.e., the probability that a change in a characteristic will yield a net performance improvement is inversely related to the pleiotropy of a characteristic (Altenberg, 1994, 1995). We call high-pleiotropy components core components and low-pleiotropy components peripheral components, because changes in high-pleiotropy components have greater repercussions for the functioning of the system as a whole than do changes in peripheral components.

The most important insight, which also is true for the structure of biological evolution, is that once a design has settled on particular variants of core components, further advances are concentrated in peripheral components only. ${ }^{6}$ It follows that even in the case of modular products, a dominant design exists, as defined by the high-pleiotropy elements: as long as particular interface standards dominate an industry, one can speak of a dominant design, even if all modules exist in hundred kinds of varieties. The architecture in Fig. $2 \mathrm{a}$ is a simple example of a complex system with an interface standard as the second element, which ensures that the first and third element can be changed independently and thus can come in many varieties. Fig. $2 b$ shows another architecture with 9 services characteristics (rows) and 12 technical characteristics (columns). Column 1 is an example of an interface standard with pleiotropy of 9 , separating technical characteristics $2-8$ from technical characteristics 9-12. Once the interface standard is fixed, one can improve service characteristics $1-5$ by manipulating technical characteristics $2-8$; service characteristics $6-9$ can be improved by manipulating technical characteristics 9-12. Column 2 can be characterized as a core component with high pleiotropy (pleiotropy of five). All other components can be characterized as peripheral because their pleiotropy is only one or two.

The structuring nature of high-pleiotropy elements is certainly not a new insight: Clark (1985) already noted this pattern of problem solving in the automobile

\footnotetext{
${ }^{6}$ In biology, the principle of mutations in low-pleiotropy components following on mutations in high-pleiotropy components, is known as constructional selection (Altenberg, 1995).
} 
history. $^{7}$ More recently, Baldwin and Clark (2000) described the same pattern for the evolution of the IBM 360 computer, with high-pleiotropy components being the technical interfaces that defined the compatibility requirements among other peripheral components. Consistent with our approach, they analyzed the interdependencies between technical and service characteristics as a matrix, the interfaces being characterized by high pleiotropy and the peripheral components by low pleiotropy. What is new compared to the early years of research on dominant designs is that with the advent of new complexity models, these principles have become formally supported, as shown by the models of Altenberg (1994, 1995), Frenken et al. (1999a), and Baldwin and Clark (2000). ${ }^{8}$

It is important to stress that although changes in core components have very low probability of success, this does not imply that these changes will never occur. What it does mean is that a change in a core component initially leading to poorer performance needs to be accompanied by many additional changes in other components,

\footnotetext{
${ }^{7}$ Early efforts in automobile design were concentrated mainly on the operational principles of different car technologies, and on their respective core subsystems and components with high pleiotropy. These included the kind of engine to use (steam, electric, gasoline), the kind of steering device (wheel, tillers), and the kind of material to use (metal, wood) (see also Henderson and Clark, 1990, p. 14). In particular, the central problem at the time concerned the reliability of cars with different fuels, an experimental stage that can be considered a period of competing core components. Once design converged to a fixed set of core concepts components (gasoline engines, steering wheels, and metal bodies), the design of core components were no longer subject to dispute, and innovations shifted towards low-pleiotropy peripheral components to fine-tune very specific functions (lamps, belt, seats, interior, catalyst, and so on) and to incrementally refine the core technologies underlying the core components (pistons, fuel inlet, and so on). As Clark $(1985,243)$ puts it: "the technical agenda was set for a variety of subsidiary problems and choices. (...) But such things would have had no place on the agenda established by the electric car. There the relevant focus for supporting technology would have included the chemistry of batteries and the parameters of electric motors". Clark (1985) also gives the example of sequential problem solving in the history of semiconductors.

${ }^{8}$ Baldwin and Clark (2000) call matrixes specifying "componentto-component" dependencies a design structure matrix (DSM). This is close to the matrix specifying the relations between technical and service characteristics because any component that affects another component will affect the service characteristics of the second component and vice versa. Thus there is a lot of informational overlap between a "pleiotropy map" and a DSM, even though one cannot be derived from the other. In both cases, core components can be singled out as having a high connectivity (as in the DSM matrix) or pleiotropy (as in our approach). In both cases, the matrix can be viewed as a network graph, in which the nodes with the highest connectivity constitute the core.
}

possibly even by architectural innovations in the way components are organized into a whole. This explains why changes in core components of a technology take so much time and effort before they are successfully introduced. It also explains why, at any level of an artifact hierarchy, technology cycles are triggered by the substitution of core components. If one accepts the concept of core components as just defined here and uses the concept of technological paradigms and dominant designs to describe the set of variants chosen for core components in an artifact, then a substitution of core components can be defined as a change in dominant design or a technological paradigm shift.

The structuring nature of standardized core components can further be illuminated by looking at the effects on the size of the relevant design space. When core components become standardized in a dominant design, the dimensions of core components are no longer considered relevant for mutation because of the low probability of success of such mutation. Consequently, the dimensions of core components, at least for some time, are no longer considered to be relevant dimensions for search for design improvements. Consider again the airplane example in Table 3: assume that the choice for the first four dimensions has become standardized. This would effectively reduce the design space from $12,960,000$ to 6000 designs. In terms of problem complexity measured by the total number of possible designs, standardization of the first four dimensions reduces the complexity by more than 2000 times!

The standardization of high-pleiotropy components in a dominant design thus reduces the relevant design space because any search is now concentrated on the dimensions of low-pleiotropy components only. By means of standardization, the time and costs involved in searching are exponentially reduced. Metcalfe (1995, pp. 35-36) has put this well, using the concept of technological paradigm: "[A] technology paradigm is a device for dealing with the tyranny of combinatorial explosion. (...) Once a workable design configuration has been established, it provides a framework for incremental artifact improvement within a stable broad knowledge and skill base. Rather than being random, technological development is guided in such a way as to reduce the rate of mutational error." To return once more to the example of the design space faced by the Wright Brothers at the start of the twentieth century (see Table 3), standardizing some of the design dimensions led to enormous reduction in the remaining design space.

Synopsis 5. A dominant design is defined by the choice of high-pleiotropy components. 
Synopsis 6. A core component is more difficult to change successfully than a peripheral component.

\subsection{Economies of scope}

Following the pleiotropy principle explained above, the term "dominant design" can now be taken to refer to a whole range of different designs that share the same variants for high-pleiotropy components. One can speak of a "design family" of varieties, all of which are based on a common core of components (Mowery and Rosenberg, 1982, p. 103; Saviotti, 1988, p. 587). The knowledge and skill to design and produce the fixed core components can then be reused at small marginal costs in many different designs, a saving better known as economies of scope. The emergence of fixed core components can be considered indicative of a technological paradigm characterized by a codified "knowledge base" of the properties of core components (Dosi, 1988) (see also Appendix A). With this codified knowledge base, different versions can be rapidly developed and efficiently produced because of economies of scope in the reuse of knowledge, skill, and equipment. Importantly, the emergence of a design family based on common core components may well imply that, although we speak of a dominant design, the variety in levels and bundles of service characteristics to users may well increase progressively. This phenomenon has been described by Gibbons et al. (1982) and Saviotti (1996), who in their studies on tractor evolution observed an increasing variety in service levels of tractors during a period a technological standardization. Understanding the emergence of a dominant design as the gradual emergence of a design family across the industry of products that share common core elements and architecture differs in important respect from the "heroic" picture of a sudden breakthrough of a single superior design or a single incidentally winning design. This point was, of course, highlighted by Abernathy and Utterback (1978) in their original formulation of the dominant theory. The dynamics in the product life cycle that lead to a dominant design is a long process of problem solving characterized by a logic that progressively leads an industry to standardize core components. Firms initially experiment with different variants of core components. Increasing returns operate in the common adoption of standard choices for core components. However, once the designs of core components have been selected, innovation no longer concentrates on mutation of core components but on designing of product varieties based on mutations in peripheral components.

At the same time that design activity shifts from core to periphery at one particular level of a system's hierarchy, a second shift takes place from higher-level problem solving to lower-level problem solving. Once designers expect the chosen solutions to core components to remain fixed for a long time, this expectation acts as a heuristic to improve this fixed core component incrementally. Consequently, problem solving travels down the hierarchy aiming to improve the chosen solution; for example, internal combustion engines in cars and jet engines in aircraft have experienced tremendous improvements since their initial use in artifacts. Within a subsystem such as the engine, lower-level subsystems such as the devices for fuel inlets, cooling systems, pistons, and so forth also got improved. From the perspective of a higher level, any improvement at a lower level can be defined as an incremental innovation (Metcalfe, 1995, p. 38) because the design at the higher level of the hierarchy does not change. But at the lower level the same innovation can be truly radical. Moreover, the greater the granularity of analysis, the more system layers are to be included in the analysis.

Studying the history of several technologies leads to the insight that architectures with both high-pleiotropy core components and low-pleiotropy peripheral components allow for the "widening" of the artifact into a design family based on standardized core and variations in the peripheral components as well as a "deepening" of the technology through incremental innovation within the fixed core components. A dominant design thus defines a so-called natural trajectory of expected improvement by widening the scope of application through innovations in peripheral components and deepening the quality of the dominant design by improving the core components (Nelson and Winter, 1977; Dosi, 1982). This also explains why many authors have stressed that designs later associated with a dominant design often emerged through an architectural innovation reorganizing components in such a way as to facilitate future innovation in peripheral components (Sahal, 1985; Baldwin and Clark, 2000; Schilling, 2000). Without asymmetry of components in terms of high and low pleiotropy, widening and deepening are less likely and can be expected to occur less rapidly because core components are less likely to stabilize.

Synopsis 7. Dominant designs allow for a systematic exploitation of economies of scope.

\subsection{Radical and incremental innovations}

Scholars have used the notion of a radical innovation in at least two distinct ways. The only common feature of these two uses is that in both cases something 
Table 4

Types of radical innovations

\begin{tabular}{lll}
\hline $\begin{array}{l}\text { Scope of new } \\
\text { knowledge }\end{array}$ & Performance improvement & High \\
\cline { 2 - 3 } & Low & Radical innovation, \\
Small & $\begin{array}{l}\text { Incremental } \\
\text { innovation }\end{array}$ & $\begin{array}{l}\text { sense 1 } \\
\text { Radical innovation, } \\
\text { Large }\end{array}$ \\
& sense 2 & innovation \\
\hline
\end{tabular}

big and exceptional happens. Radical innovations have been defined either in terms of their antecedents (the scope of new knowledge required) or in terms of their consequences (the increased performance they make possible). ${ }^{9}$ Given these two different dimensions of radicalness, an innovation could be incremental in terms of the new knowledge required but radical in terms of the additional performance achieved, and vice versa (see Table 4). Most scholars do not distinguish between these two meanings, which makes it difficult to interpret in what sense they see an innovation as being radical. When one becomes aware of these two dimensions of radicalness, innovations that require large amounts of new knowledge and create large performance improvements clearly have a particular potential to transform industrial structures. To distinguish this kind of innovation from the others, we propose to call it a radical-square $\left(r^{2}\right)$ innovation.

How does this innovation typology relate to the concept of a systems hierarchy? In terms of an innovation along the new knowledge dimension, moving up the systems hierarchy (i.e., encompassing more and more components) by definition means that an innovation is becoming more radical because the design of more and more components is being based on new principles. This is not true, however, for the performance dimension of innovations. Here, innovations that occur at lower levels can have more radical consequences than innovations that involve the entire system. In fact, most rapid improvements in technological history have typically taken place along well-defined technological trajectories (Dosi, 1982; Nelson and Winter, 1982; Sahal, 1985). This means that radical innovations (in terms of both dimensions) can occur at the individual component, individual subsystem, or a higher level of aggregation. Empirical research needs to track the exact location

\footnotetext{
${ }^{9}$ Ehrnberg (1995) provides a very good discussion of the confusion between the two meanings of radical innovation in the innovation studies literature. See also Levinthal (1998), who develops important theoretical implications of the two meaning of radical innovation for evolutionary theories of industrial change.
}

where the innovations takes place and examine what impact a particular location of innovation has on the industrial organization of the production system.

Synopsis 8. Innovations can be radical either in terms of their antecedents (the scope of new knowledge required) or in terms of their consequences (the increased performance they make possible).

Synopsis 9. Moving upward in the systems hierarchy increases the radicalness of innovation in terms of the scope of new knowledge required.

\subsection{A systematic hierarchical model of dominant designs}

On the basis of our conceptualization of technology as a complex hierarchical system that is brought about through a search in a nested hierarchy of design spaces, we are now in the position to articulate a model of dominant designs as a nested hierarchy of technology cycles. By proposing a clear set of ideas, our model tries to provide an integration of the different strands of dominant designs research.

\subsubsection{Definition of dominant design}

A dominant design exists in a technological class when the majority of designs have the same technologies for the high-pleiotropy core components. Interfaces can constitute such core components because interfaces can be high-pleiotropy elements in a complex system. Pleiotropy thus determines which subsystems/interfaces are core and which are peripheral. The notion of a majority of designs can be defined empirically by using either a threshold (e.g., 50, 40, 30, 20\%) measure or a variety measure (e.g., entropy; Herfindahl index). Although the semantics of dominant design may suggest that the concept has a binary meaning (either an industry is or is not characterized by a dominant design in), for scientific purposes the concept of dominant design is best viewed as representing a continuum. This means that a design can be more or less dominant in an industry (Afuah and Utterback, 1997). To assure comparable findings, the way in which dominance of a design is measured needs to be reported. Also the geographic areas and industries covered in the empirical analysis need to be identified.

\subsubsection{The unit of analysis}

Because artifacts can be conceptualized as complex hierarchical systems, there are multiple units of analysis. The overall artifact constitutes the system and its lower levels comprise a nested hierarchy of subsystems. At the 
bottom level of this hierarchy are the basic components that make up the technology (see Fig. 1). Systems differ in terms of their breadth (how many basic components they possess) and depth (how many levels of subsystems they possess). At each level are linkages (interfaces) that integrate components into a subsystem or subsystems into systems. To specify a unit of analysis unambiguously, one needs to define both the level above and the level below the focal unit of analysis.

\subsubsection{Granularity of analysis}

Dominant designs exist only when the artifact is described at intermediate degrees of granularity. Because the range of levels between the two extremes of granularity can be very wide, the level of granularity adopted in a particular study needs to be specified by identifying what would count as one granularity level finer and what would be one granularity level coarser. Technologies differ in their speed of development. To be able to replicate findings concerning the dynamics of change in a particular technology, one must also specify the time interval used for the unit observation.

\subsubsection{Temporal sequencing}

The cyclical nature of technological development follows from the distinction between core and peripheral subsystems and components and from the definition of a dominant design as standardized core components/interfaces. A substitution of core subsystems or components starts a new cycle at the respective level of the hierarchy. Innovation thus proceeds in nested cycles marked by episodes of variation, selection and retention processes (see Fig. 3).

\subsubsection{Causal mechanisms}

Our model describes artifacts and the types of changes they can be expected to undergo over time. The adoption of core components and interfaces generates increasing returns through various mechanisms previously described by Arthur (1989). Network externalities may be a sufficient condition in some industries. Because we cannot derive from our model that network externalities are a necessary condition for a dominant design, at this point it is useful to leave open the possibility that other mechanisms play a role. We expect mechanisms to differ in their relative importance depending on the nature of the technology, its interface with the users, and the socio-political regime.

\subsubsection{Boundary conditions of model}

Our model applies to complex artifacts. But just as Simon (1962) and Alexander (1964) thought, we believe virtually all artifacts are complex systems because designers need to consider-even in the case of artifacts that look simple and composite-numerous relevant design dimensions that interact in complex and unpredictable ways.

\section{Linking technological dynamics to organizational outcomes}

Management scholars and industrial organization economists have been keenly interested in the dynamics of change in technological artifacts because the structure of artifacts has a profound effect on the organization of the industrial system that produces them. One can interpret the entire history of dominant design research as an attempt to find a theory that would map technological changes to changes in the industrial organization of firms and markets. Although scholars have not discovered such a one-to-one mapping between technological events and industrial events, they have uncovered large amounts of evidence showing that technological changes powerfully shape the range of different organizational arrangements possible at any given moment. Oliver Williamson (1985) squarely recognized the technological circumscription of any industrial organization when he defined as the most fundamental transaction the one "when a good or service is transferred across a technologically separable interface (p. 1)". This means that knowledge about the changes in the structure of a technological system will allow one to make predictions about what industrial organizations are possible for a particular production system and what industrial organization is unlikely or even impossible to emerge. At the same time, though, market structures provide incentives for developing certain types of innovation over other types. Before a dominant design emerges, for example, many small firms engage in product innovation in an attempt to develop and appropriate the knowledge underlying the future dominant design, or parts of it. After a dominant design emerges, and the industry has become concentrated, firms have an incentive to engage in process innovations, the costs of which can be spread over many products (Klepper, 1997). This means that changes in technology and market structure are causally connected.

Although many scholars recognize the importance of technical change in explaining industrial dynamics, many studies attempted to explain industrial dynamics solely from a demographic perspective (Carroll and Hannan, 2000; Klepper and Simons, 1997; Klepper, 2002). This research strategy is probably motivated, at least in part, by the lack of a consistent nomenclature 


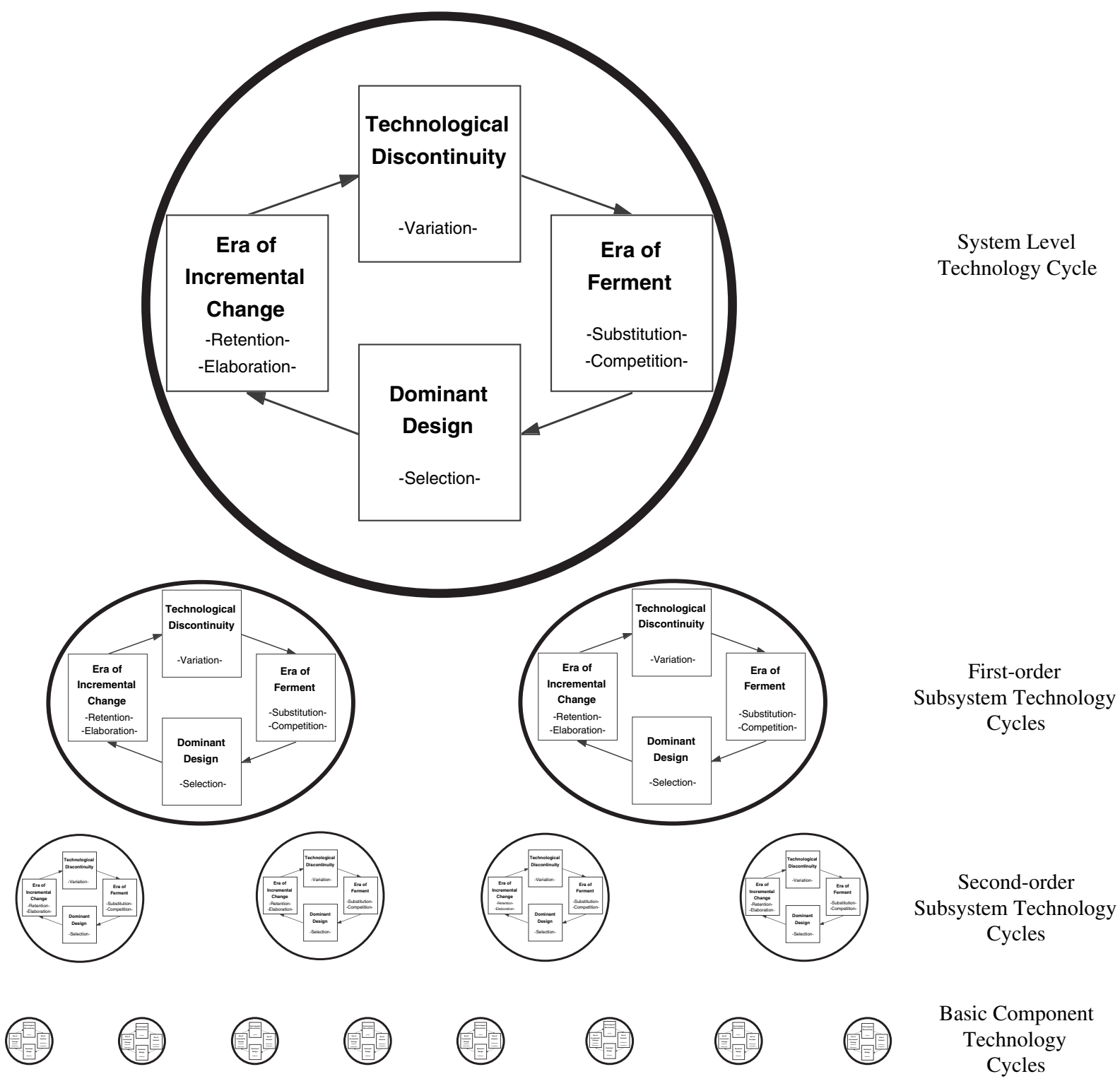

Fig. 3. Nested hierarchy of technology cycles.

of technical change. One of the roadblocks lying in the way of making more progress in spelling out the causal links between technological innovation and industrial changes is precisely that empirical research on dominant designs has not consistently conceptualized technologies in terms of a hierarchical system and has not specified the unit of analysis of the particular research results reported. By using the hierarchical model formulated above, we believe researchers will be able to gather more systematic data to trace the organizational and strategic consequences of innovations at the different levels of the artifact structure. As has been noted by several authors (cf. Christensen and Rosenbloom, 1995; Baldwin and Clark, 2000), production systems that manufacture complex technologies also have a hierarchical structure. The purpose of this section is to introduce a typology of firms participating in the production system hierarchy, to review what we already know about the relationship between technological and industrial change, and to spell out some of the fruitful research questions opened up by looking at these connections through the lens of hierarchy theory. 
The production of any technological systems can be organized in a variety of ways. Relying completely on the market as a coordinating mechanism, every basic component and subsystem could in principle be made by a different firm and one firm would assemble the final product from first-order subsystems purchased in the market. Alternatively, at the other end of the spectrum, a single firm could fully coordinate the production of a technological system by making within its boundaries everything from the basic component to the full system. The hierarchical organization of physical artifacts implies that there can be a parallel nested hierarchy of producers and markets. Christensen and Rosenbloom (1995) have used the notion of a value-network to highlight the important fact that firms can be located at many points of the design hierarchy and be more or less vertically and horizontally integrated.

Because to date the empirical literature on dominant design has not systematically adopted a hierarchical view of artifacts, dominant design research has been chiefly concerned with the horizontal and not the vertical organization of industries (Klepper, 1997). To understand the consequences for the industrial organization of different kind of innovations at various locations in the systems hierarchy, it is important to distinguish between firms whose boundaries circumscribe different components and subsystems. In tracking the impact of innovations in different locations of the artifact structure, it would be very useful if future research efforts distinguish clearly between component manufacturers, subsystem assemblers, and final system assemblers. Just as we counted levels in the artifact from the system level on down (see Fig. 1), we want to identify clearly the various firms that participate in producing a technological system by using a variation of the Fujimoto (1999) supplier typology. We propose that future research use a production typology that distinguishes between system assemblers, first-tier subassemblers, second-tier subassemblers, etc., all the way down to the basic component makers and raw material makers. This implies that demographic studies in the tradition of Suarez and Utterback (1995), Carroll and Hannan (2000) and Klepper (2002) could fruitfully track the co-evolution of industrial dynamics of different, yet technologically related industries.

In the 1970s Rothwell directed at the Science Policy Research Unit (SPRU) of the University of Sussex a systematic study of attempted innovations in chemicals and scientific instruments industries, testing 200 factors that have been hypothesized to discriminate systematically between innovations that became commercial
Table 5

Abernathy and Clark's (1985) innovation typology

\begin{tabular}{lll}
\hline Markets customer & \multicolumn{2}{l}{ Technology/production competences } \\
\cline { 2 - 3 } linkages & Conserve/entrench & Disrupt/obsolete \\
\hline Conserve/entrench & Regular & Revolutionary \\
& innovation & innovation \\
Disrupt/create & Niche creation & Architectural \\
new & innovation & innovation \\
\hline
\end{tabular}

successes and commercial failures (see Freeman and Soete, 1997, pp. 204-218, for an excellent summary). Of the 200 factors, only a small number, principally related to marketing, discriminated in a statistically significant way between successes and failures. The most decisive discriminator was the extent to which firms understood user needs from the very beginning of the innovation effort. The evidence from these and other studies suggests that successful innovation is in essence a coupling process focusing superior technological competencies in products and processes to meet the specific needs of users. Users are quite willing to switch to rival technologies once they learn a new technology offers them significant cost savings, more closely matches their requirements (i.e., an improvement in quality), or both.

Consistent with these research findings, we believe that Abernathy and Clark's (1985) typology highlighting the power of an innovation to disrupt the organization of an existing production system and the connections of existing firms to markets and customers has pointed in the right direction for future research on the relationship between technological innovations and industrial outcomes (see Table 5). What is so valuable about this typology is that it focuses at the same time on the ability of an innovation either to conserve the positions of existing firms or to render their technological and marketing capabilities obsolete. Employing this typology along with the hierarchical model of technical artifacts and production systems should enable investigations to show with much greater precision how innovations in different parts of the technological system affect an existing industrial organization.

Previous empirical research has already provided evidence that the speed of change in the overall system and different subsystems and in the components of a technical artifact is not the same. Scholars have also shown that the firms making up the production system are affected differently by innovations, depending on what parts of the system they make. In the case of the automobile industry, which stimulated the development 
of dominant design theory, the entry and exit patterns at the system level (automobile assemblers) were quite different from the industrial dynamics associated with one of the first-order subsystems, tires. The number of automakers in the U.S. peaked in 1909 (Klepper, 1997), whereas the number of tire producers peaked in 1922 (Klepper, 1997). In another industry, Miller et al. (1995) documented that there was very little turnover in the flight-simulator industry from one product generation to the next at the level of the overall system assemblers but there was a large amount of turnover at the level of subsystem assemblers and component manufacturers. Similarly, consistent with traditional dominant design theory, after a dominant design emerged in main-frame computing (the IBM System/360 architecture), entry into the system assembly segment of the industry seems to have been reduced. But as Baldwin and Clark (2000, pp. 377-378) report, emergence of the system-level dominant design stimulated an enormous number of entries at the subsystem level. The number of publicly traded subsystem assemblers increased from 95 in 1970 to 244 in 1980, with twice as many firms entering than exiting during this period. Such a vertical disintegration of the production system took place even more dramatically later in the PC segment of computers (Langlois and Robertson, 1992).

What becomes clear from our discussion is that the industrial dynamics at the system, subsystems, and components levels is not the same and, indeed, is not predicted to be the same by our theory of dominant designs. Higher-order design developments, especially standardization, greatly affect industrial dynamics at lower levels, and one can formulate specific hypotheses about these dynamics. To the extent that standardization opens new markets for modular components, standardization may also trigger entry at a lower subsystem level while forcing firms to exit at the system level. The hierarchical model of dominant designs and the industrial organization raises a large number of interesting hypotheses about how technical innovations at different levels of the artifact structure affect the boundaries and the fate of the firms making up the production system. We expect firms that produce components with high pleiotropy (core components and core subsystems) to have greater influence on bringing about important dominant designs. Similarly, at any level of the hierarchy, we expect firms that produce components with high pleiotropy to be more successful, and more persistently so, than firms producing components with a lower pleiotropy, because the knowledge and resources characterizing the former firms are more complex and less easy to imitate than those underlying the latter firms. Furthermore, we expect the effects of radical innovations in a particular subsystem to be more negative on firms that assemble the particular subsystem and on their network of suppliers than on firms that are higher-level assemblers. Thus, everything else being equal, firms higher up the hierarchy have a greater control over their life course than those at lower levels of the hierarchy.

We also point the reader to an essay by Robertson and Verona (2006), which articulates other interesting hypotheses about how technological change will affect the boundaries of the firm. These hypotheses can be reformulated in terms of the hierarchical model we advocate here. Some scholars have suggested that the integrated Chandlerian firm will become much less frequent in the economy as the production system becomes much more vertically disintegrated, using standard interfaces and markets as mechanisms for coordination (Sanchez and Mahoney, 1996; Schilling, 2000; Baldwin and Clark, 2000). But other scholars have voiced skepticism that production systems are going to become fully modular (Brusoni and Prencipe, 2001; Robertson and Verona, 2006). The concepts and empirical research methodology outlined in this paper make it possible to investigate this question systematically.

\section{Conclusion: the value of standardization in dominant design research}

In the preceding pages we have articulated the benefits that accrue for the development of technologies by standardizing core components or core interfaces of the system. Without such standardization, designers quickly become overwhelmed by the complexity of the search process, and parallel experimentation with different designs for peripheral components is not possible. As Baldwin and Clark (2000) have noted, however, only after designers have accumulated sufficient knowledge about the internal structure of a technical system is it advantageous to modularize the system by specifying design rules and interfaces that all subsystems have to follow.

After three decades of research on dominant designs, the time has come to reap the benefits of creating a more formal model and standardizing the language through which researchers report their empirical studies. We have very consciously tried to create a more formalized model of dominant designs, and we propose a nomenclature to describe technical artifacts as well as the industrial organization of the underlying production system that is general enough yet retains sufficient analytic bite that other researchers will not experience it as a straightjacket for their own research efforts. To make the adoption 
of this nomenclature more likely, we have also pulled together in this paper what we regard as the best analytical concepts for studying the relationship between technical changes and industrial developments. Our goal is to lower the entry barriers for new scholars to research this fertile area. The cost for individual researchers to follow the proposed nomenclature seems relatively small, while the benefits of doing so appear very large: if scholars were to use our proposed standardized language, each study-although conceived and executed independently - would automatically contribute to an ever-growing and cumulative shared body of knowledge about the relationship between technological and industrial change.

\section{Acknowledgements}

We thank two sets of three anonymous reviewers for suggestion on how to improve the paper. One anonymous reviewer deserves credit for pointing us to the work of Kuhn (1962). We also are grateful to Michael Tushman, Richard Nelson, Steven Klepper, Brian Loasby, Sendil Ethiraj and participants of the December 2001 conference on production theory at the Max Planck Institute of Economics (Jena, Germany) for helpful comments on drafts of this paper. We are especially imdebted to Carliss Baldwin for many useful suggestions on the different versions of this paper.

\section{Appendix A. On the structural similarity of dominant designs and scientific paradigms}

There is an important similarity between dominant designs and scientific paradigms. The emergence of invariant core components in technologies has a parallel with the emergence of invariant core assumptions in scientific research programs. The similarity justifies the use of the term paradigms in both scientific and technological development. Invariant core assumptions in research programs are indicative of codification in scientific paradigms (Kuhn, 1962), alike to invariant core components in product families (Dosi, 1982, 1988; Martin, 1983; Saviotti, 1986). Both scientific paradigms and technological paradigms are constituted around a particular stable "knowledge base" regarding the underlying core scientific and technological principles (Dosi, 1988). The codification of the knowledge base facilitates spill-over of knowledge (Cowan and Foray, 1997).

The pleiotropy principle, which explains why mutations in technological systems tend to be restricted to peripheral components, parallels the image of Lakatos
(1970, 1978) of a "protective belt" of auxiliary assumptions that ensure the continued acceptance of core assumptions of a scientific paradigm. Once a set of core assumptions is established, research concentrates on adapting auxiliary assumptions to specific empirical settings. According to Lakatos (1970, 1978), invariant core assumptions function as a negative heuristic, in the sense that research should not concentrate on changes in these assumptions. Auxiliary assumptions, however, function as a positive heuristic; that is, research activity should concentrate on changes in these assumptions to enlarge the scope of application of a paradigm. Similarly, changes in core components of a technological paradigm tend to be postponed, but changes in peripheral components of a technology enlarge the scope of application of invariant core components (cf. Dosi, 1982, p. 152, footnote 16).

In our model, Lakatos' classification of heuristics can be translated in terms of the effects of the heuristics on the relevant design space. A negative heuristic can be defined as a heuristic that reduces the number of dimensions of the design space because it indicates in which components one should not look for solutions (don'ts). Auxiliary assumptions function as a positive heuristic in the sense that changes in these assumptions enlarge the scope of application of a paradigm (do's). Positive heuristics define the relative design space because they indicate where one should look for new solutions (Frenken, 2001, 2006).

\section{References}

Abernathy, W.J., 1978. The Productivity Dilemma: Roadblock to Innovation in the Automobile Industry. Johns Hopkins Press, Baltimore.

Abernathy, W.J., Utterback, J., 1978. Patterns of industrial innovation. Technology Review 50, 41-47.

Abernathy, W.J., Clark, K.B., 1985. Innovation: mapping the winds of creative destruction. Research Policy 14, 3-22.

Adner, R., Levinthal, D., 2001. Demand heterogeneity and technology evolution: implications for product and process innovation. Management Science 47 (5), 611-628.

Afuah, A.N., Utterback, J.M., 1997. Responding to structural industry changes: a technological evolution perspective. Industrial and Corporate Change 6 (1), 183-202.

Alexander, C., 1994. Notes on the Synthesis of Form, 13th ed. Harvard University Press, Cambridge, MA, and London.

Altenberg, L., 1994. Evolving better representations through selective genome growth. In: Proceedings of the IEEE World Congress on Computational Intelligence, pp. 182-187.

Altenberg, L., 1995. Genome growth and the evolution of the genotype-phenotype map. In: Banzhaf, W., Eckman, F.H. (Eds.), Evolution and Biocomputation. Springer-Verlag, Berlin and Heidelberg.

Anderson, P., Tushman, M.L., 1990. Technological discontinuities and dominant designs: a cyclical model of technological change. Administrative Science Quarterly 35 (4), 604-633. 
Arthur, W.B., 1989. Competing technologies, increasing returns, and lock-in by historical events. The Economic Journal 99 (394), 116-131.

Baldwin, C.Y., Clark, K.B., 1997. Managing in an age of modularity. Harvard Business Review 75 (Sep-Oct), 84-93.

Baldwin, C.Y., Clark, K.B., 2000. Design Rules, vol. 1. The Power of Modularity. MIT Press, Cambridge, MA.

Baum, J.A.C., Korn, H.J., Kotha, S., 1995. Dominant designs and population dynamics in telecommunications services: founding and failure of facsimile transmission service organizations, 1965-1992. Social Science Research 24, 97-135.

Bradshaw, G., 1992. The airplane and the logic of invention. In: Giere, R. (Ed.), Cognitive Models of Science. University of Minnesota Press, Minneapolis.

Brusoni, S., Prencipe, A., 2001. Unpacking the black box of modularity: technology, product, and organisation. Industrial and Corporate Change 10, 179-205.

Burg, U., Von Kenney, M., 2000. Venture capital and the birth of the local area networking industry. Research Policy 29 (9), 1135-1155.

Carroll, G.R., Hannan, M.T., 2000. The Demography of Corporations and Industries. Princeton University Press, Princeton, NJ.

Chesbrough, H., 1999. Arrested development: the experience of European hard disk drive firms in comparison with US and Japanese firms. Journal of Evolutionary Economics 9 (3), 287-329.

Christensen, C.M., Rosenbloom, R.S., 1995. Explaining the attackers advantage: technological paradigms, organizational dynamics, and the value network. Research Policy 24, 233-257.

Christensen, C.M., Suarez, F.F., Utterback, J.M., 1998. Strategies for survival in fast-changing industries. Management Science 44 (12), S207-S220.

Clark, K.B., 1985. The interaction of design hierarchies and market concepts in technological evolution. Research Policy 14, 235-251.

Cowan, R., 1990. Nuclear power reactors: a study in technological lock-in. Journal of Economic History 50, 541-567.

Cowan, R., Foray, D., 1997. The economics of knowledge codification and diffusion. Industrial and Corporate Change 6 (3), 595-622.

Cusumano, M.A., Mylonadis, Y., Rosenbloom, R.S., 1992. Strategic maneuvering and mass-market dynamics: the triumph of VHS over Beta. Business History Review 66 (Spring), 51-94.

David, P.A., 1975. Technical Choice, Innovation and Economic Growth. Essays on American and British Experience in the Nineteenth Century. Cambridge University Press, London.

David, P.A., 1985. Clio and the economics of QWERTY. American Economic Review 75 (2), 332-337.

Dennett, D., 1995. Darwin's Dangerous Idea. Simon and Schuster, New York.

Dosi, G., 1982. Technological paradigms and technological trajectories. A suggested interpretation of the determinants and directions of technical change. Research Policy 11, 147-162.

Dosi, G., 1988. The nature of the innovative process. In: Dosi, G., Freeman, C., Nelson, R., Silverberg, G., Soete, L. (Eds.), Technical Change and Economic Theory. Pinter, London.

Ehrnberg, E., 1995. On the definition and measurements of technological discontinuities. Technovation 15 (7), 437-452.

Ethiraj, S.K., Levinthal, D., 2004. Modularity and innovation in complex systems. Management Science 50 (2), 159-173.

Freeman, C., 1968. Chemical process plant: innovation and the world market. National Institute Economic Revue 45, 29-51.

Freeman, C., Soete, L., 1997. The Economics of Industrial Innovation, third ed. The MIT Press, Cambridge, MA.

Frenken, K., 2001. Fitness landscapes, heuristics and technological paradigms: a critique on random search models in evolutionary economics. In: Dubois, D. (Ed.), Computing Anticipatory Systems. American Institute of Physics, Woodbury, NY.

Frenken, K., 2006. Innovation, Evolution and Complexity Theory. Edward Elgar, Cheltenham and Brookfield.

Frenken, K., Marengo, L., Valente, M., 1999a. Interdependencies, neardecomposability and adaptation. In: Brenner, T. (Ed.), Computational Techniques for Modelling Learning in Economics. Kluwer Academic Publishers, Boston.

Frenken, K., Saviotti, P.P., Trommetter, M., 1999b. Variety and niche creation in aircraft, helicopters, motorcycles and microcomputers. Research Policy 28, 469-488.

Fujimoto, T., 1999. The Evolution of a Production System at Toyota. Oxford University Press, NY.

Gibbons, M., Coombs, R., Saviotti, P., Stubbs, P.C., 1982. Innovation and technical change. A case study of the U.K. tractor industry, 1957-1977. Research Policy 11, 289-310.

Gort, M., Klepper, S., 1982. Time-paths in the diffusion of product innovations. Economic Journal 92, 630-653.

Hagedoorn, J., Carayannis, E., Alexander, J., 2001. Strange bedfellows in the personal computer industry: technology alliances between IBM and Apple. Research Policy 30 (5), 837-849.

Hatfield, D.E., Tegarden, L.F., Echols, A.E., 2001. Facing the uncertain environment from technological discontinuities: hedging as a technology strategy. Journal of High Technology Management Research 12 (1), 63-76.

Henderson, R.M., Clark, K.B., 1990. Architectural innovation: the reconfiguration of existing product technologies and the failure of established firms. Administrative Science Quarterly 35, 9-30.

Henderson, R., 1995. Of life cycles real and imaginary: the unexpectedly long old age of optical lithography. Research Policy 24 (4), 631-643.

Hounshell, D.A., 1984. From the American System to Mass Production. Johns Hopkins University Press, Baltimore.

Hughes, T.P., 1983. Networks of Power. Johns Hopkins University Press, Baltimore.

Iansiti, M., Khanna, T., 1995. Technological evolution, system architecture and the obsolescence of firm capabilities. Industrial and Corporate Change 4 (2), 333-361.

Islas, J., 1999. The gas turbine: a new technological paradigm in electricity generation. Technological Forecasting and Social Change 60 (2), 129-148.

Kauffman, S.A., 1993. The Origins of Order. Self-Organization and Selection in Evolution. Oxford University Press, NY and Oxford.

Kauffman, S.A., Lobo, J., Macready, W.G., 2000. Optimal search on a technology landscape. Journal of Economic Behavior and Organization 43, 141-166.

Khazam, J., Mowery, D., 1994. The commercialization of RISC: strategies for the creation of dominant designs. Research Policy 23, 89-102.

Klepper, S., 1996. Entry, exit, growth, and innovation over the product life cycle. American Economic Review 86 (3), 562-583.

Klepper, S., 1997. Industry life cycles. Industrial and Corporate Change $6,145-182$.

Klepper, S., 2002. The capabilities of new firms and the evolution of the US automobile industry. Industrial and Corporate Change 11 (4), 645-666.

Klepper, S., Simons, K.L., 1997. Technological extinctions of industrial firms. Industrial and Corporate Change 6, 379-460.

Kuhn, T.S., 1962. The Structure of Scientific Revolutions. University of Chicago Press, Chicago. 
Lakatos, I., 1970. Falsification and the methodology of scientific research programmes. In: Lakatos, I., Musgrave, A. (Eds.), Criticism and the Growth of Knowledge. Cambridge University Press, Cambridge.

Lakatos, I., 1978. The Methodology of Scientific Research Programmes. Cambridge University Press, Cambridge.

Langlois, R.N., Robertson, P.L., 1992. Networks and innovation in a modular system: lessons from the microcomputer and stereo component industries. Research Policy 21, 297-313.

Levinthal, D., 1998. The slow pace of rapid technological change: gradualism and punctuation in technological change. Industrial and Corporate Change 7 (2), 217-248.

Liebowitz, S.J., Margolis, S.E., 1995. Path dependence, lock-in, and history. Journal of Law, Economics and Organization 11 (1), 205-226.

Martin, M.J.C., 1983. On Kuhn, Popper, and teaching technological innovation management. European Journal of Operational Research 14, 221-227.

Matthews, R.C.O., 1984. Darwinism and economic change. In: Collard, D.A., Dirnsdale, N.H., Gilbert, C.L., Helm, D.R., Scott, M.F.G., Sen, A.K. (Eds.), Economic Theory and Hicksian Themas. Clarendon Press, Oxford (reprinted in: U. Witt (Ed.), 1993. Evolutionary Economics. Edward Elgar, Aldershot, UK).

Metcalfe, J.S., 1995. Technology systems and technology policy in an evolutionary framework. Cambridge Journal of Economics 19, 25-46.

Mowery, D.C., Rosenberg, N., 1982. The commercial aircraft industry. In: Nelson, R.R. (Ed.), Government and Technical Progress. A Cross-Industry Analysis. Pergamon Press, NY.

Miller, R., Hobday, M., Leroux-Demers, T., Olleros, X., 1995. Innovation in complex system industries: the case of flight simulation. Industrial and Corporate Change 4 (2), 363-400.

Mokyr, J., 2002. The gifts of Athena: historical origins of the knowledge economy. Princeton University Press, Princeton, N.J.

Nelson, R.R. (Ed.), 1962. The Rate and Direction of Inventive Activity: Economic and Social Factors, vol. 13. Princeton University Press, Princeton, NJ.

Nelson, R.R., 1995. Co-evolution of industry structure, technology and supporting institutions, and the making of comparative advantage. International Journal of the Economics of Business 2 (2), 171184.

Nelson, R.R., Winter, S.G., 1977. In search of a useful theory of innovation. Research Policy 6 (1), 36-76.

Nelson, R.R., Winter, S.G., 1982. An Evolutionary Theory of Economic Change. The Belknap Press of Harvard University Press, Cambridge.

Pinch, T.J., Bijker, W.E., 1984. The social construction of facts and artifacts: or how the sociology of science and the sociology of technology might benefit each other. Social Studies of Science 14, 399-442.

Polanyi, M., 1962. Personal Knowledge: Towards a Post-Critical Philosophy. Harper \& Row, NY.

Robertson, P.L., Verona, G., 2006. The effects of technological change on the boundaries of existing firms. In: McKelvey, M., Holmén, M. (Eds.), Flexibility and Stability in the Innovating Economy. Oxford University Press, Oxford.

Rosenberg, N., 1969. The direction of technological change: inducement mechanisms and focusing devices. Economic Development and Cultural Change 18, 1-24.

Rosenbloom, R.S., Cusumano, M.A., 1987. Technological pioneering and competitive advantage: the birth of the VCR industry. California Management Review 29 (4), 51-76.
Rosenkopf, L., Tushman, M.L., 1993. On the co-evolution of technology and organization. In: Singh, J., Baum, J. (Eds.), The Evolutionary Dynamics of Organizations. Oxford University Press, NY.

Rosenkopf, L., Nerkar, A., 1999. On the complexity of technological evolution: exploring coevolution within and across hierarchical levels in optical disc technology. In: Baum, J.A.C., McKelvey, B. (Eds.), Variations in Organization Science: In Honor of Donald T. Campbell. Sage Publications, Thousand Oaks, CA.

Sahal, D., 1985. Technological guideposts and innovation avenues. Research Policy 14, 61-82.

Sanchez, R., Mahoney, J.T., 1996. Modularity, flexibility, and knowledge management in product and organization design. Strategic Management Journal 17, 63-76.

Sanderson, S.W., Uzumeri, M., 1995. Managing product families: the case of the Sony Walkman. Research Policy 24, 761-782.

Saviotti, P.P., 1986. Systems theory and technological change. Futures $18,773-786$.

Saviotti, P.P., 1988. The measurement of changes in technological output. In: Van Raan, A.F.J. (Ed.), Handbook of Quantitative Studies of Science and Technology. North-Holland, Amsterdam.

Saviotti, P.P., 1996. Technological Evolution, Variety and the Economy. Edward Elgar, Cheltenham and Brookfield, UK.

Saviotti, P.P., Metcalfe, J.S., 1984. A theoretical approach to the construction of technological output indicators. Research Policy 13, 141-151.

Schilling, M.A., 2000. Toward a general modular systems theory and its application to interfirm product modularity. Academy of Management Review 25, 312-334.

Simon, H.A., 1962. The architecture of complexity: hierarchic systems. Proceedings of the American Philosophical Society 106 (December), 467-482.

Simon, H.A., 1969. The Sciences of the Artificial, third ed. MIT Press, Cambridge/MA, 1996.

Simon, H.A., 2002. Near decomposability and the speed of evolution. Industrial and Corporate Change 11 (3), 587-599.

Suarez, F.F., 2004. Battles for technological dominance: an integrative framework. Research Policy 33, 271-286.

Suarez, F.F., Utterback, J.M., 1995. Dominant designs and the survival of firms. Strategic Management Journal 16, 415-430.

Teece, D.J., 1986. Profiting from technological innovation: implications for integration, collaboration, licensing and public policy. Research Policy 15, 285-305.

Thomke, S., Hippel, E.V., 2002. Customers as innovators: a new way to create value. Harvard Business Review 80 (4), 74-81.

Tushman, M.L., Rosenkopf, L., 1992. On the organizational determinants of technological change: towards a sociology of technological evolution. Research in Organizational Behavior 14, 311347.

Tushman, M.L., Murmann, J.P., 1998. Dominant designs, technology cycles and organizational outcomes. Research in Organizational Behavior 20, 231-266.

Ulrich, K., 1995. The role of product architecture in the manufacturing firm. Research Policy 24, 419-440.

Utterback, J.M., Suarez, F.F., 1993. Innovation, competition, and industry structure. Research Policy 22 (1), 1-21.

Van de Ven, A.H., Garud, R., 1993. The co-evolution of technical and institutional events in the development of an innovation. In: Singh, J., Baum, J. (Eds.), The Evolutionary Dynamics of Organizations. Oxford University Press, NY.

Vincenti, W.G., 1990. What Do Engineers Know and How Do They Know It? Johns Hopkins Press, Baltimore. 
Vincenti, W.G., 1991. The scope for social impact in engineering outcomes: a diagrammatic aid to analysis. Social Studies of Science 21, 761-767.

Vincenti, W.G., 1994. The retractable landing gear and the Northrop "anomaly": variation-selection and the shaping of technology. Technology and Culture 35 (1), 1-33.

Wade, J., 1995. Dynamics of organizational communities and technological band wagons: an empirical investigation of community evolution in the microprocessor market. Strategic Management Journal 16, 113-133.
Williamson, O.E., 1985. The Economic Institutions of Capitalism. Free Press, NY.

Wilson, D., 1969. Forms of hierarchy: a selected bibliography. General Systems 14, 3-15.

Windrum, P., Birchenhall, C., 1998. Is life cycle theory a special case? Dominant designs and the emergence of market niches through coevolutionary learning. Structural Change and Economic Dynamics 9, 109-134. 